\title{
AN ARCHAEOLOGICAL SURVEY OF THE COOLOOLA REGION, S.E. QUEENSLAND
}

\section{IAN MCNIVEN}

Anthropology \& Sociology

University of Ruetensl and

\section{THE COOLOOLA REGION ARCHAEOLOGICAL PROJECT}

Within the last decade a general model of Aboriginal subsistence and settlement has emerged for coastal southeast Queensland. Investigations have concentrated in two areas, Fraser Island (Devitt 1979, Lauer 1977, 1979,) and Moreton Bay (Alfredson 1983, 1984, Crooks 1982, Draper 1978, Hall 1980, 1982a, 1984, Hall and Robins 1984, Richardson 1979, 1984, Robins 1983, Robins and Hall 1981, Stockton 1974, Walters 1980). The general ethnohistorical and archaeological scenario for these two areas suggests semi-permanent coastal settlement with a subsistence orientation to marine protein resources (Devitt 1979, Hall 1982). The coastal archaeological record between these two areas however remains virtually unknown.

The Cooloola Region is located between Fraser Island and Moreton Bay, immediately north of Noosa (Figure 1). It is dominated by the Cooloola sandmass, the largest continuous series of sand dunes found anywhere in the world (Seymour 1984:4). Its proximity and environmental similarity to Moreton Bay and Fraser Island (see Coaldrake 1961, 1962, Thompson 1975, 1981), suggested that archaeological research at Cooloola would augment studies of Aboriginal coastal adaptation in southeast Queensland as well as coastal Australia generally. More specifically, my interest was to reconstruct a settlement-subsistence system for the area. Thus, the Cooloola Region Archaeological Project (C.R.A.P.) was established and Stage 1 - an initial survey focusing on the sandmass - was initiated (McNiven 1984). This paper presents the major findings of that research.

\section{Stage 1 - The initial survey}

The general aims of this study follow what is generally accepted as the primary research objectives of initial regional archaeological investigations.

1. Discovery of the range and form of archaeological manifestations with preliminary information on their relative frequencies and spatial arrangement. Such information should be sought through a site survey (Ammerman 1981:66, Binford 1964, Redman 1973:64, 1974:23, Schiffer, Sul1ivan and Klinger 1978:17). 
2. An attempt should be made to integrate these characteristics within an environmental framework to allow hypothetical statements concerning subsistence and settlement behaviour in the study area (see Ammerman 1981, Reher 1977).

3. The generalized and extensive nature of these investigations will allow the identification of more specific problem areas for future archaeological work, relating not only to the peculiarities of the study area, but also to the study of cuiture process and adaptation in similar and nearby environments (see Canouts 1977:136).

The large size of the Cooloola Region (62,000 ha) coupled with limiting factors of time and personnel, precluded a general reconnaissance survey of the entire region. The survey was therefore restricted to the east of the Noosa River, an area herein designated as the Cooloola Survey Area. Such division is not totally arbitrary given basic environmental differences on both sides of the river (see below). The Cooloola Survey Area comprises some 40,000 ha, of which about $1-2 \%$ was actually surveyed during the two-month field period.

\section{THE STUDY AREA}

\section{Climate}

The mild sub-tropical climate of the region is partly manifested in the average annual rainfall of $1500 \mathrm{~mm}$. Mean maximum and mean minimum temperatures for the hottest months (January to March) are near $270 \mathrm{C}$ and $200 \mathrm{C}$ respectively, for the coolest months (July and August) $210 \mathrm{C}$ and $100 \mathrm{C}$ respectively (Thompson and Moore 1984).

\section{Geology and Geomorphology}

The Cooloola Region consists of six physiographic units (Thompson and Moore 1984) (Figure 1). The low sandstone hills comprise the western catchment of the Noosa River and dip to the east, passing under the sandmass. Coastal sand plains surround the majority of the Noosa River and its associated waterways and flank most of the eastern periphery of $T$ in Can Bay. The strand plain consists of a succession of low sand ridges aligned subparallel to the present coastline. The Double Island Point promontory consists of andesite flanked on its southeastern margin by hills of aeolinite. The lower reaches of the Noosa River are dominated by large, brackish lakes. Numerous smaller perched lakes occur on the sandmass. The huge sand dunes constituting the sandmass result from eight episodic periods of dune building spanning possibly over 760,000 years (Ward, Little and Thompson 1979:314). The dune systems are aligned subparallel to the present coastline and extend some $10 \mathrm{~km}$ inland achieving elevations of up to $260 \mathrm{~m}$ above sea level.

\section{Soils}

The Cooloola Region exhibits a complex mosaic of soil types, the majority being either variant or differentially developed podzols. Humus podzols and acid peats predominate the coastal sand plains, whilst the low sandstone hills are characterized by lateritic podzols and podzolic lithosols. Soils on the strand plain are dominated by podzols and humus podzols (i.e. Inskip Point [IP] soil landscape). Each 


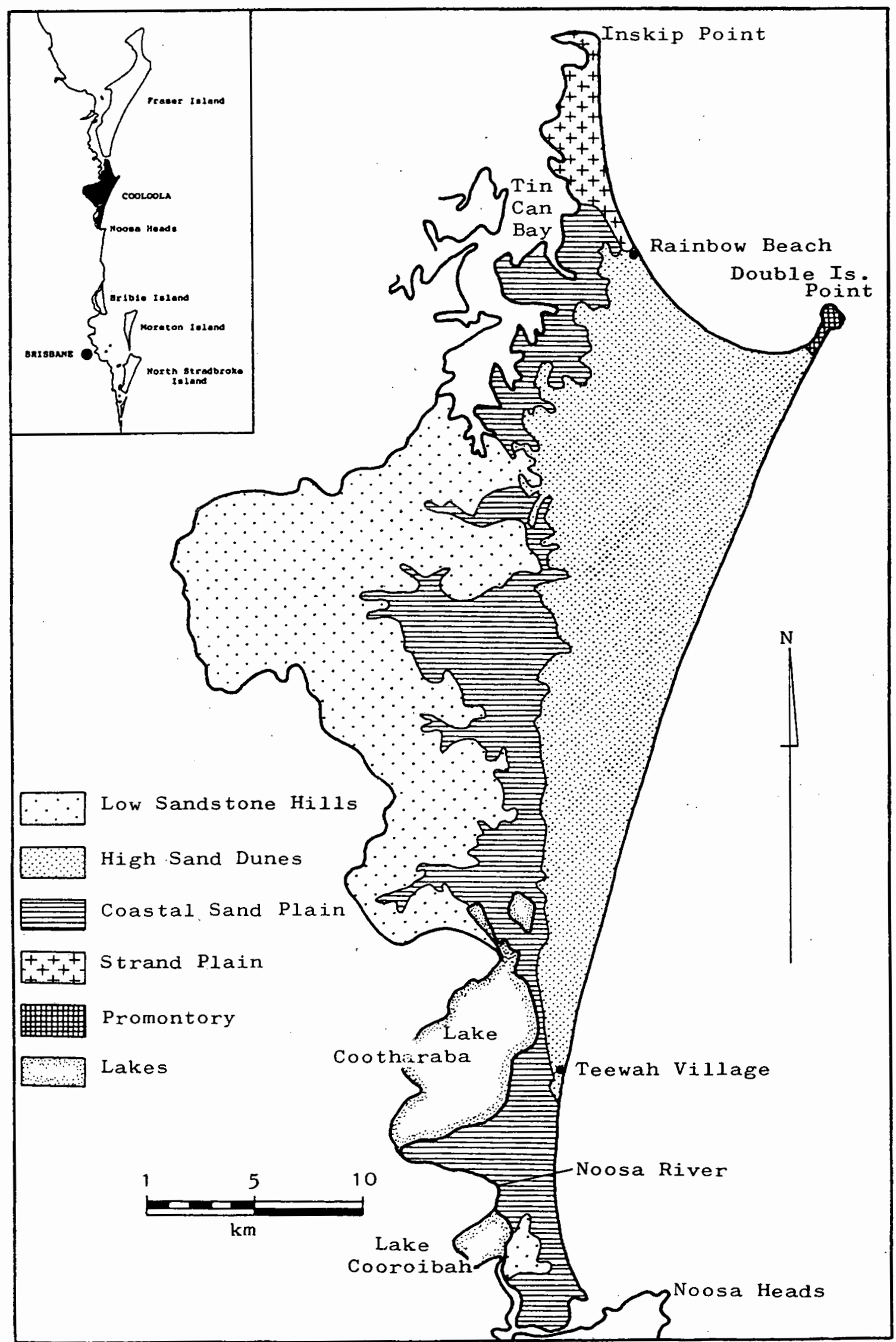

Figure 1. Physiographic units of the Cooloola Region (after Thompson and Moore 1984:4). 
sand dune system on the sandmass has a distinct soil profile, manifesting a relative chronosequence with the oldest dune system having the greatest depth of soil profile development (Thompson 1983). As a result, the six soil landscapes for the sandmass (Mutyi, Chalambar, Burwilla, Warrawonga, Mundu and Kabali - abbreviated to M, C, B, W, $M D$ and $K$ respectively here after) represent the western exposed portions of dune systems 1 to 6 respectively (C. Thompson, pers. comm. 1985).

\section{Vegetation}

The Cooloola Region exhibits a strong association between plant communities and type and degree of soil formation (Coaldrake 1961, Thompson and Moore 1984, Walker et al. 1981, Webb and Tracey 1975). On the low sandstone hills open Eucalypt forests predominate on ridges giving way to Melaleuca forests in low lying areas. The majority of vegetation on the coastal sand plains is swampy in character (eg. Melaleuca and Casuarina forests, Banksia heaths and sedgelands) with Eucalypt forests and woodlands restricted to higher and drier areas.

A succession of plant communities following the alignment of the six exposed sand dune systems exists on the sandmass. Vegetation progresses from shrubby woodlands of Banksia, Casuarina and Pandanus along the coastal periphery (dune system 1) through to vineforest on dune system 4 (see Webb and Tracey 1975). On ridges and slopes surrounding the corridor area of vineforest occurs tall open forests of predominately blackbutt (Eucalyptus pilularis). Beyond this is found an extensive zone of medium to low forest and woodland dominated by Eucalyptus signata (Thompson and Moore 1984).

\section{Fauna}

The vegetation mosaic of Cooloola has produced a highly diverse vertebrate fauna. However, in comparison to species 1 ists from similar heathland contexts in southeast Queensland and northeast New South Wales, Cooloola lacks 16 species of mammals, 73 species of terrestrial birds, 23 species of reptiles and three species of frogs. In general, the mammals of Cooloola are characterized by low total species richness, very low within-habitat diversity, low abundance and low density (Dwyer, Hockings and Willmer 1979, Dwyer, Kikkawa and Ingram 1979, Gravatt and Ingram 1975).

\section{Hydrology}

The Cooloola region comprises the Noosa River catchment. The Noosa River is a result of relatively consistent spring flows from the Como scarp to the west and the sandmass to the east (Stanton n.d.). Numerous springs and spring fed creeks flank the sandmass. Eastern sandmass springs emanate from Teewah Beach and the southern half of Wide Bay. Shallow watertables occur on the coastal sand plains and strand plain physiographic units.

\section{European environmental impact}

Due to inherent infertility of most of the Cooloola Region, European land use of the area has been minimal. Selective logging commenced in the region in the early 1860's, concentrating on the vineforests (Kerr 1970, Straker 1968:5-6). In the early 1960's and 1970's sand mining occurred north of Rainbow Beach and south of Teewah Village. 


\section{SURVEY STRATEGY}

The regional approach necessitates recourse to sampling theory, and recent 1 iterature concerning archaeological sampling procedures and techniques is both copious and often contradictory (see Binford 1964, Mueller 1975, Plog 1976, Plog, Plog and Wait 1978, Redman 1974, Schiffer, Sullivan and Klinger 1978).

For any survey area a sampling strategy can be formulated irrespective of existing information on the area (eg. simple random or simple systematic sample survey). Likewise, use can be made of extant information to stratify the area into more homogeneous strata resulting in greater accuracy and less error in the sample estimate (see Stopher and Meyburg 1979). All archaeological survey strategies should consider the environmental diversity and location of previously recorded sites in the study area. The development of a simple site type-site location model should be attempted. This will result in two basic strata; first, areas hypothesized to contain certain site types and, second, areas where no idea on the form and location of archaeological phenomena exists (see Plog, Plog and Wait 1978:405). Irrespective of the basis for stratification, some attempt should be made to sample the environmental diversity within the survey area. It is only when these factors have been considered that more theoretical aspects of sample strategy formulation should be undertaken.

\section{Site definition}

For the Cooloola study a site was defined as any place exhibiting evidence suggestive of Aboriginal activity. Following Godwin (1982) and Robins (1983) a distance of $10 \mathrm{~m}$ between archaeological phenomena was used as an arbitrary measure of site discreteness.

\section{Visibility}

Earlier reconnaissance of the survey area demonstrated that due to vegetation cover and leaf litter accumulation, areas open enough for profitable surveying were usually rare, small in area and sporadically distributed (see Greenslade and Thompson 1981). Thus, they negated the possibility of prior locality prediction and hence incorporation into a survey strategy.

The disturbance mechanisms of erosion (eg. coastal, dune blowout), humans (eg. settlements, roads) and fires were of a cegree of predictability which did allow incorporation into a survey strategy. The Cooloola survey strategy faced the dilemma of either looking in these areas or initiating subsurface probing. Time restrictions and the size of the survey area excluded the latter option.

\section{Stratification}

The development of a detailed hypothetical site type-location model for the entire study area was not possible given, firstly, the existence of only scant archaeological data for Cooloola and, secondly, the inadequate and generalized nature of settlement-subsistence models for other coastal areas in southeast Queensland. However, previous archaeological research in coastal southeast Queensland (eg. Moreton, Bribie and North Stradbroke Islands) did allow the development of a simple hypothetical model of site type-location for certain similar environmental contexts in the Cooloola Survey Area as follows: 
1. Estuarine coastline (eastern periphery of Tin Can Bay): shell middens composed primarily of oyster, cockles and whelks. Stone artefacts are probably present.

2. Ocean surf beach (Inskip Point to mouth of Noosa River): shell middens composed primarily of pipi shells with rocky platform species entering middens near Double Island Point. Stone artefacts are probably present.

3. Dune blowouts (ie. eastern periphery of sandmass): stone artefact scatters.

Based on the above, the Cooloola survey area was divided into two major sampling strata:

Stratum 1 - Areas where certain site types were predictable and freshwater sources.

Stratum 2 - Areas where no information is available to warrant a hypothetical site type-location model.

\section{Sampling unit shape}

Given the aims of this project, recent studies suggested that transects (as opposed to quadrats) would be more accurate and efficient (see Plog 1976, Plog, Plog and Wait 1978:401, Sanders, Parsons and Santley 1979:528, Schiffer, Sullivan and Klinger 1978:12). The 1 inear arrangement of areas in Stratum 1 makes the deployment of transects easy. However, for sandblows the oval shape suggested a general reconnaissance would be more appropriate. Regarding the placement of transects for the vast majority of the survey area (ie. Stratum 2), orienting transects perpendicular to major environmental zones would be more accurate and efficient (Reher 1977:8, Matson and Lipe 1975:132, Schiffer, Sullivan and K1inger 1978:17).

\section{Stratum 1}

1. Coastlines: The ubiquitous erosion face along both the estuarine and oceanic coast 1 ines delineated transects. As time and personnel restrictions negated a total survey, a $50 \%$ random sample of $1 \mathrm{~km}$ long transects was chosen. The $60 \mathrm{~km}$ long eastern periphery of $T$ in $C$ an $B$ ay provided 30 of these transects. The oceanic coastline was divided into three sections due to the general inaccessiblity of the cliff tops in Section 2, and the coastal bifurcation at Double Island Point (Figure 2). The $14 \mathrm{~km}$ of Section 1 and the $51 \mathrm{~km}$ of Section 3 allowed 7 and 25.5 transects respectively. Three transects of Section 2 were chosen for surveying (Figure 2).

2. Sandblows: As sandblows were few in number $(n=15)$, all were selected for survey.

3. Freshwater sources: Unfortunately all lakes and waterways were surrounded by dense vegetation which inhibit ground inspection. The exception was Lake Poona, whose $10 \mathrm{~m}$ wide beach provided a circular transect. 


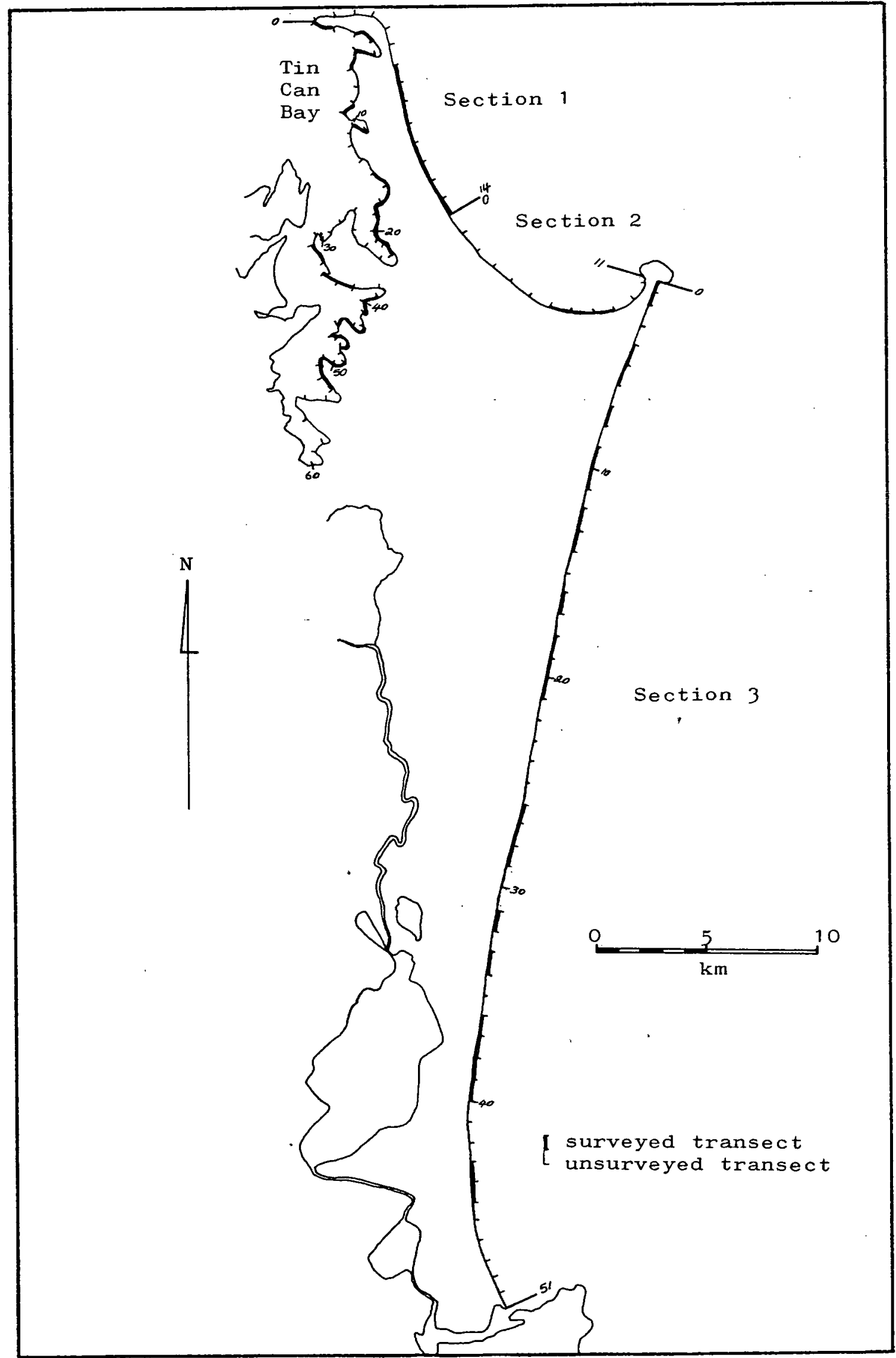

Figure 2. Surveyed and unsurveyed coastal transects. 


\section{Stratum 2}

Visibility restrictions limited the theoretical placement of transects. However, as an extensive network of logging tracks crisscrosses the survey area, and as many run in a NW-SE direction (ie. traversing all major environmental zones) it was deemed valid to employ them as survey transects. Sandtracks were ranked according to orientation and number of soil landscapes crossed. Consequently, all major NW-SE sandtracks crossing from the east to the west side of the survey area were assigned first priority. For comparison a number of sandtracks running in a general S-N direction were assigned second priority.

During the survey bushfires occurred at Double Island Point, Poverty Point and south of Teewah Village greatly enhancing visibility. Areas of each were selectively surveyed according to accessibility and time availability.

Application of the site definition along the sandtrack transects was 1 imited by the occurrence of scatterings of shell fragments along them. This apparent lack of midden discreteness (in contrast to that observed along the oceanic coastline) resulted in the employment of a non-site survey strategy. The number and type of archaeological materials for each metre of transect was recorded. Most sandtracks were 3-4 metres wide, resulting in density measures for every $3-4 \mathrm{~m}^{2}$ of transect.

\section{Stone artefacts}

Except for areas within the immediate vicinity of rock outcrops, all rocks occurring within the survey area can be assumed to be at least manuports. Five stone artefact types were hypothesized to be found during the survey. They include three morphological types (flakes, flaked pieces and cores - see Hiscock 1984:129), one functional type ("bevelled pounders" - see Kamminga 1981, Gillieson and Hal1.1982) and manuports.

\section{SURVET RESULTS}

The site survey of the eastern periphery of Tin Can Bay, Wide Bay and Teewah Beach coastlines, bushfired areas, sandblows and lakes yielded 102 sites (Figure 3). All consisted of either shell midden deposits (with or without associated stone artefacts and bone) or stone artefact scatters. One of the major implications of these results was the efficacy of the site type-location model.

\section{Teewah Beach}

Twenty-four of the 26 transects were surveyed. A total of 42 sites were located in 11 of these. Forty (95.3\%) consisted of shellfish remains, of which 13 also contained stone artefacts. Two sites exhibited stone artefacts only (sites 4 and 22). Al1 middens contained pipi (Donax deltoides) shells, but site 31 also exhibited gastropod shells and site 27 contained fish bone.

A comparison of the observed and expected number of sites per transect (Poisson frequency distributions and Chi Square) suggests the existence of too few transects containing sites, indicating non-random site clustering in particular transects. 


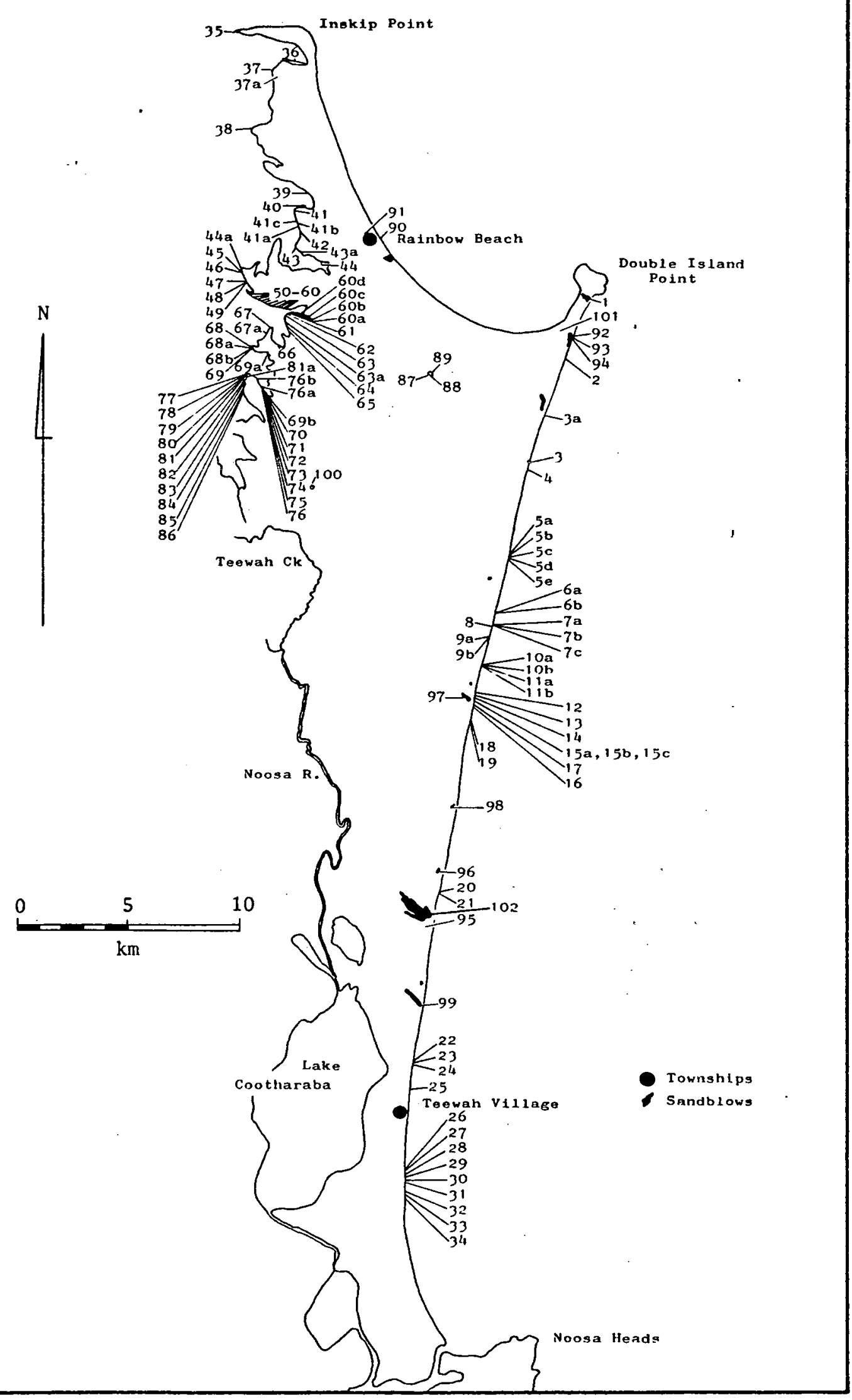

Figure 3. Sites recorded in the Cooloola survey area. 
In order to gain some insight into sight location along Teewah Beach three major environmental contextual variables were recorded for each site including proximity to freshwater, proximity to pandanus trees and, elevation above beach.

Over $90 \%$ of sites are within $500 \mathrm{~m}$ of a visible freshwater source with over $75 \%$ as close as $50 \mathrm{~m}$ (Table 1 ). To test the relative significance of this association, survey transects were divided into $500 \mathrm{~m}$ segments and the total observed and expected frequencies for the concurrence of visible freshwater sources and sites were compared using a contingency table and Chi-square analysis. The results suggest a strong association (randomness $P=<0.001$ )

Table 1. Proximity of Teewah Beach sites to fresh water.

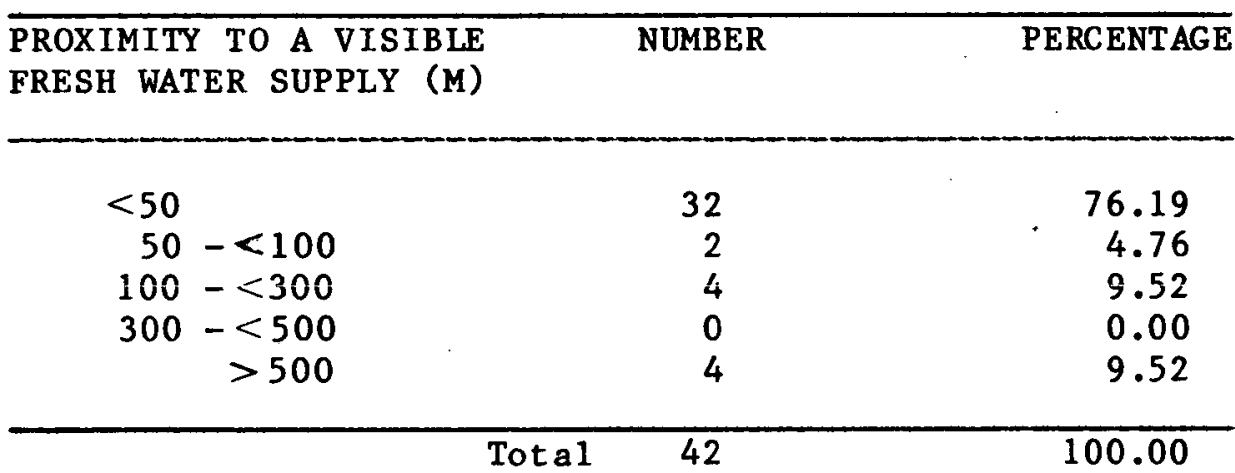

Site elevation was hypothesized to influence site location due to the effort required to ascend the sandy 35 degree slopes, many of which are over $100 \mathrm{~m}$ in height. Site elevations ranged from $2.0 \mathrm{~m}$ to $28.3 \mathrm{~m}$ $(x=12.9 \mathrm{~m})$. Future testing for the significance of this figure will require comparison with elevations for the remainder of the survey transect areas. However, given that huge slopes characterize this coast the mean site elevation appears to reflect a site location bias to lower elevations.

Fewer than $20 \%$ of sites have pandanus trees further than $100 \mathrm{~m}$ away, with $64.3 \%$ of sites being within $10 \mathrm{~m}$ (Table 2). Although no information is available to test the significance of this association, a number of middens were located directly beneath isolated pandanus trees suggesting a causal association (eg. sites 18 and 19).

Table 2. Proximity of Teewah Beach sites to Pandanus.

\begin{tabular}{|c|c|c|}
\hline $\begin{array}{l}\text { PROXIMITY TO A PANDANUS } \\
\text { TREE (M) }\end{array}$ & NUMBER & PERCENTAGE \\
\hline $\begin{array}{r}<10 \\
10-100 \\
>100\end{array}$ & $\begin{array}{r}27 \\
7 \\
8\end{array}$ & $\begin{array}{l}64.29 \\
16.67 \\
19.05\end{array}$ \\
\hline
\end{tabular}


Intra-site metrical variables recorded for each site are summarized in Table 3. The distribution of these variables along the coast produced interesting patterns (Figures $4,5, \& 6$ ). The two areas of coast exhibiting most of the sites (ie. the second and 1 ast $10 \mathrm{~km}$ sections) show great variation in values. This pattem appears to be a true characterization of sites along Teewah Beach and is not due to sampling error given that areas of coast with few or no site recordings were adequately sampled (see Figure 2).

Table 3. Characteristics of Teewah Beach and Tin Can Bay sites.

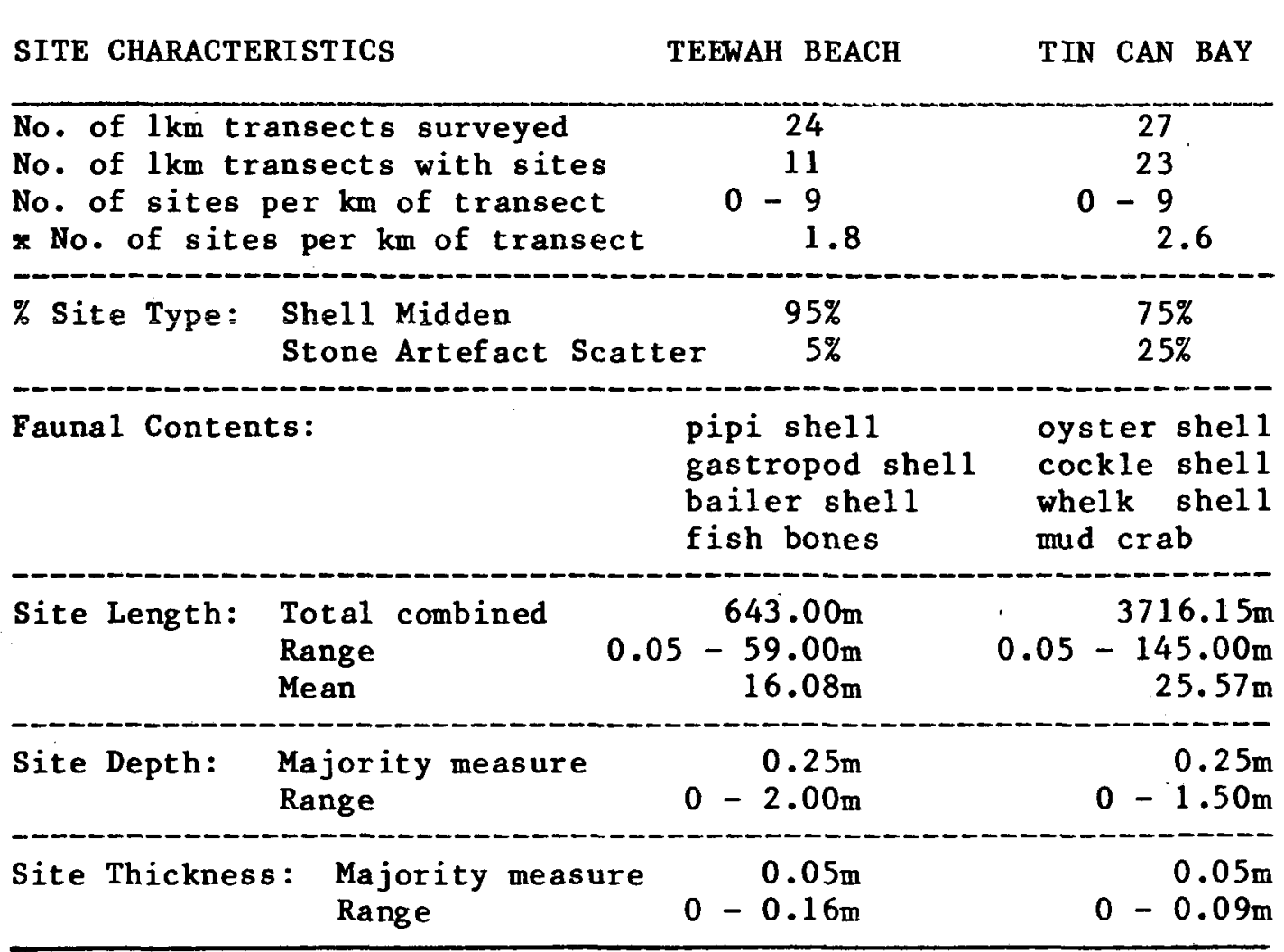

\section{Tin Can Bay}

Twenty-four of the randomly chosen transects and three non-random ly chosen transects were surveyed. A total of 69 sites were located within 23 transects. Fifty-two sites $(75.4 \%)$ consisted of shel1 middens, of which 17 also yielded stone artefacts. Seventeen sites (24.6\%) exhibited stone artefacts only. All shell middens consisted of varying proportions of cockle (Anadara trapezia), whelk (Pyrazus ebeninus) and oyster (Crassostrea commercialis) she11s. The only other recorded faunal remains was a mud crab (Scylla serrata) claw fragment at site 57.

As with the Teewah Beach survey results comparison of the observed and expected number of sites per transect indicated non-random site clustering in particular transects.

The environmental contextual variable hypothesized to have correlativity in site location along the estuarine coastline was vegetation type. The $45 \%$ sample of coastline resulted in $17.5 \mathrm{~km}(64.8 \%)$ and $9.5 \mathrm{~km}$ (35.2\%) of the transects being covered by open forest and swamp respectively, the two major vegetation types. A null hypothesis can be formulated which states that if the 69 sites are distributed independent of 
vegetation type, then ca. $65 \%$ of sites should be located within open forest. In fact, $91.3 \%(n=63)$ are located in open forest with only $8.7 \%$ $(n=6)$ being located in swampy areas. Interestingly, all swamp sites consisted solely of stone artefact scatters and all shell middens were located in open forest. The intra-site metrical variables recorded for Tin Can Bay sites are the same as those recorded for Teewah Beach (Table 3), again resulting in a number of interesting trends. The change in site length along the eastern periphery of $T$ in Can Bay is erratic, with longer sites dominating the centre of the coast (Figure 7). Both site thickness and site depth exhibit a similar trend with larger values occurring along the southern half of the coastline (Figures 8 and 9).

\section{Wide Bay}

The survey of this coastline was totally abandoned due to inaccessibility and subsequent knowledge of coastal sand mining along the northern $6 \mathrm{~km}$ of the bay. A total survey of unmined coastline north of Rainbow Beach and the $3 \mathrm{~km}$ transect from Section 2 resulted in the location of one site, situated at Rainbow Beach. It consists of the scant remains of a pipi shell midden without stone artefacts approximately $100 \mathrm{~m}^{2}$ in area.

\section{Bushfired areas}

Bushfired areas yielded two sites. The Poverty Point fire exposed a $53 \mathrm{~m}$ stone artefact scatter along the coast (site 69b), whilst the Double Island Point fire revealed a pipi shell midden adjacent to a small permanent waterhole (site 101) (Figure 3).

\section{Lakes}

The perimeter of Lake Poona yielded five stone artefacts (sites 87 , 88 and 89 ). A small midden containing estuarine shell species also exists along the northwestern periphery of Weber Swamp (site 100) (C. Thompson pers. comm).

\section{Sandblows}

Ten of the approximately 15 sandblows within the survey area were examined. All but two yielded archaeological evidence (Figure 10), all contained stone artefacts and four also yielded faunal material (sites $1,92,93,94,3$ and 97 ). Sites 1,93 and 94 contained pipi and gastropod shells, the remainder comprised solely of pipi shell. All sites were surface scatters except site 1 which exhibited charcoal and an andesite manuport (exposed in section $5-6 \mathrm{~m}$ below the surface).

All stone artefacts at sites 99,98 and 3 were recorded. The large number of artefacts in sites 1,97 and 96 were characterized by sampling (see McNiven 1984:104-107 for details). No formal artefact recording was done at sites $92,93,94$ and 102 due to time restrictions.

\section{Sandtrack Transects}

Eight $W-E$ transects and $12 \mathrm{~S}-\mathrm{N}$ transects totaling some $59 \mathrm{~km}$ and $37 \mathrm{~km}$ respectively were surveyed (Figure 11 ). Due to lack of time sections of Logging Area and South of King's Bore Road S-N transects and North W-E transect were incompletely recorded. Disregarding these, some 31,000 shell fragments and 112 stone artefacts were recorded. 


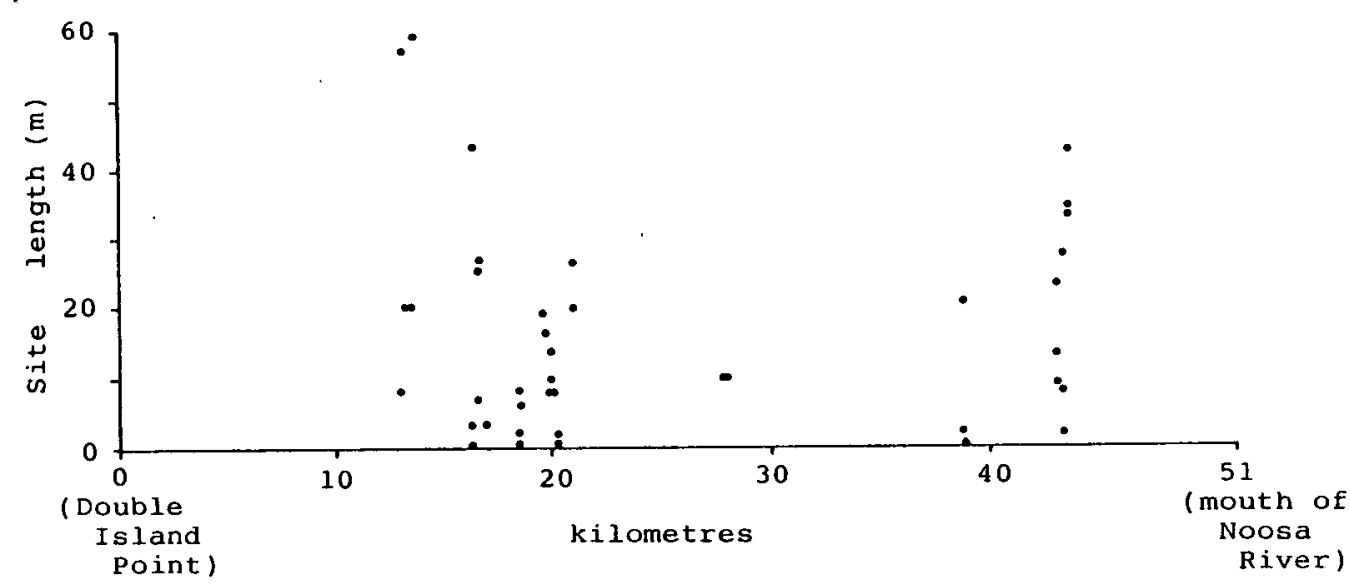

Figure 4. Distribution of site length along Teewah Beach.

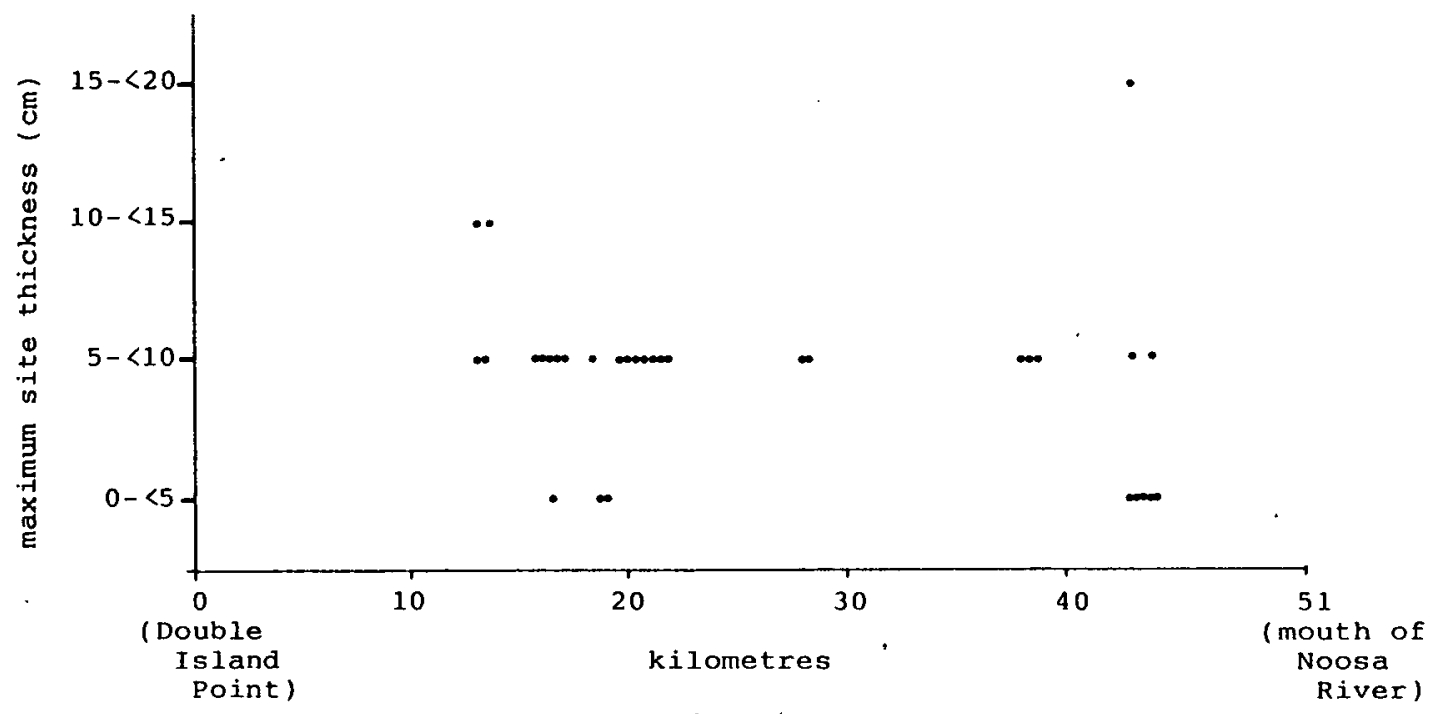

Figure 5. Distribution of site thickness along Teewah Beach.

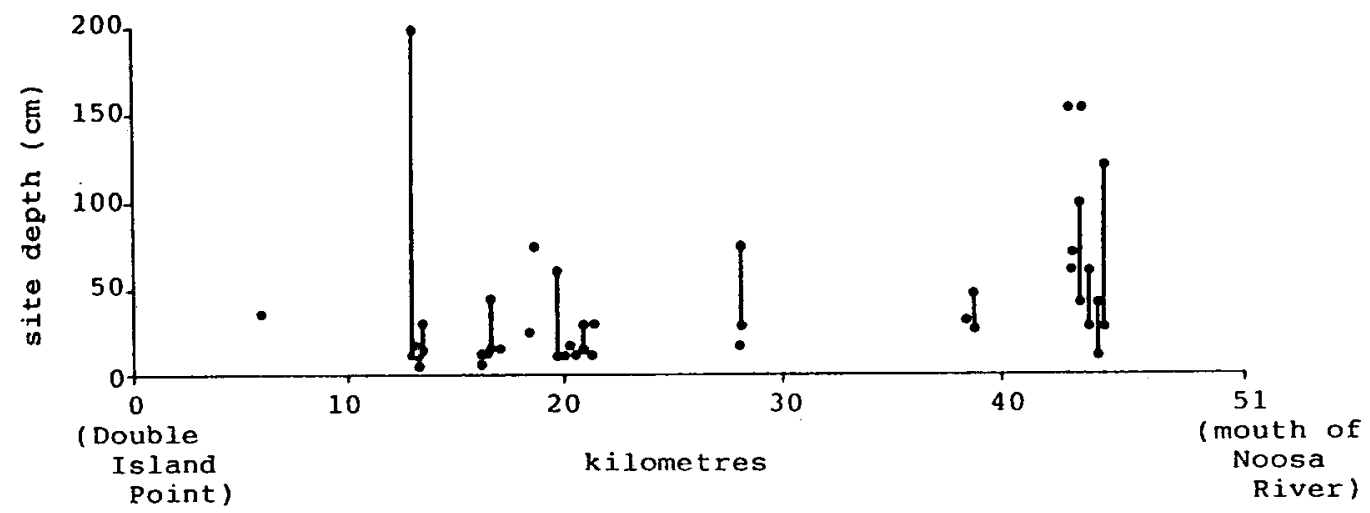

Figure 6. Distribution of site depth along Teewah Beach. 


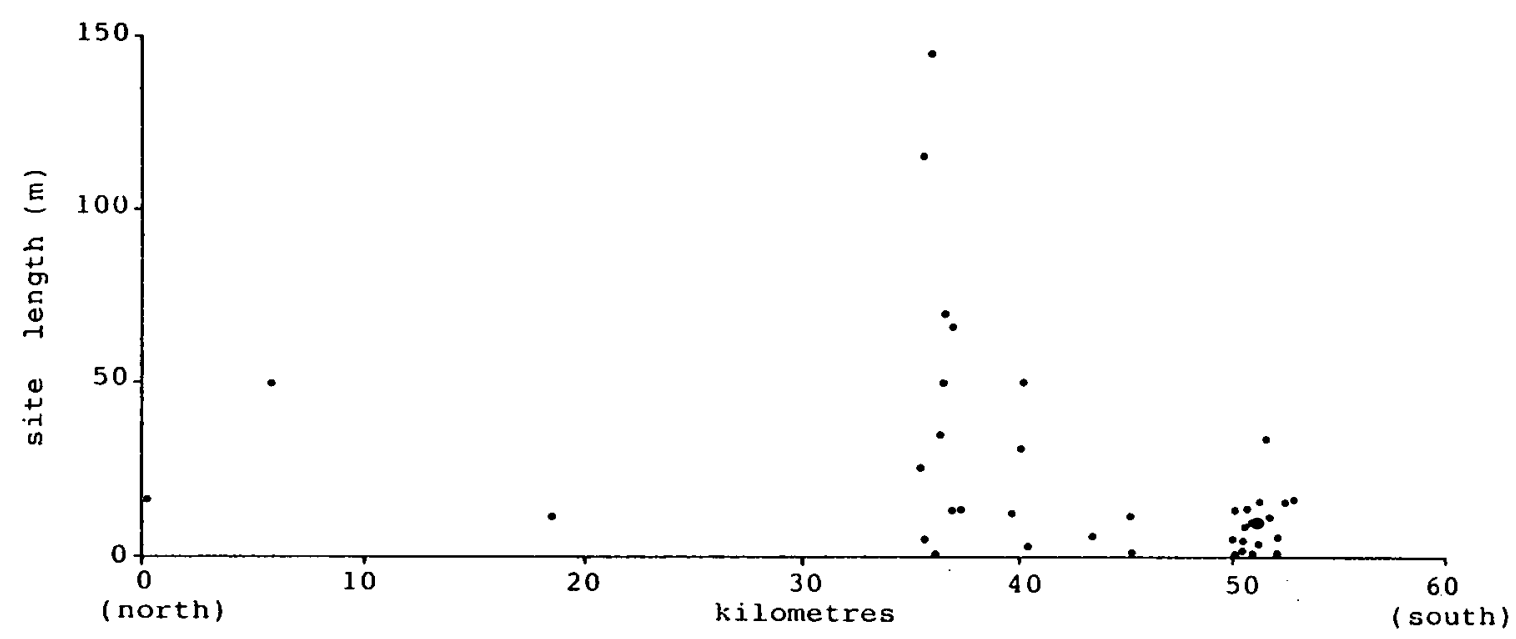

Figure 7. Distribution of site length along Tin Can Bay.

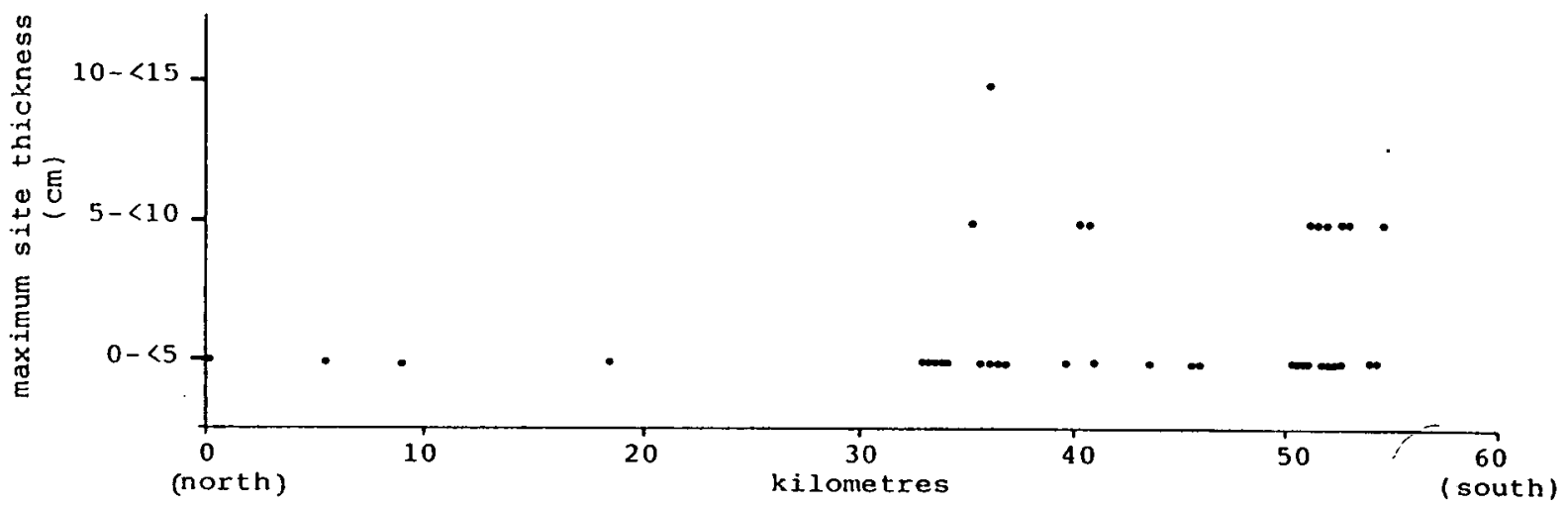

Figure 8. Distribution of site thickness along Tin Can Bay.

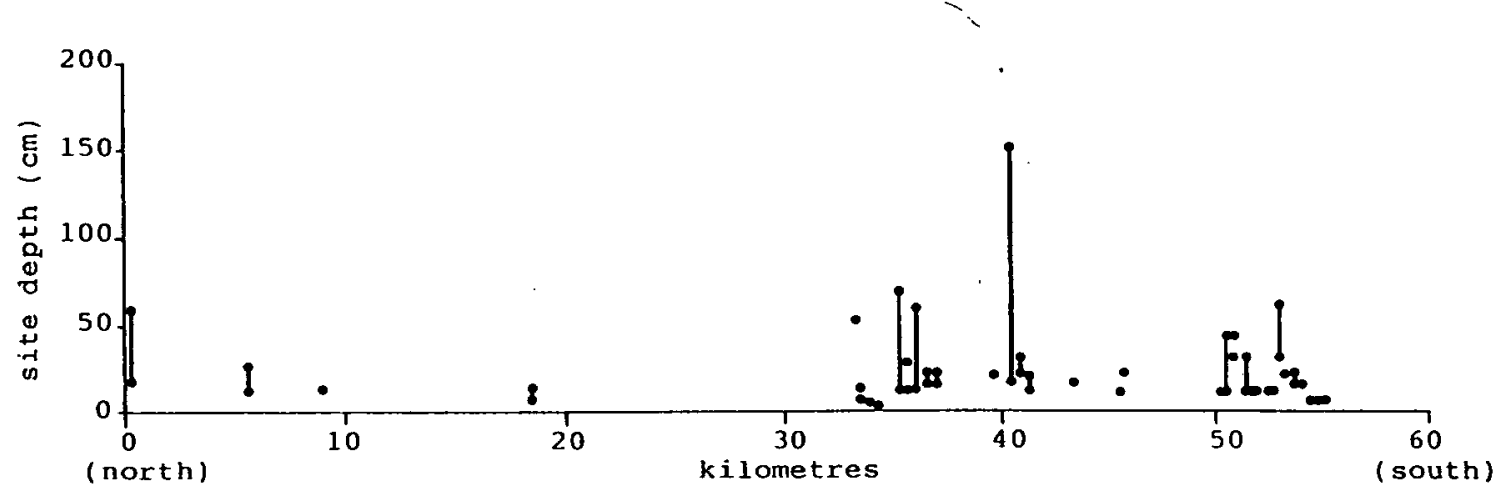

Figure 9. Distribution of site depth along Tin Can Bay. 


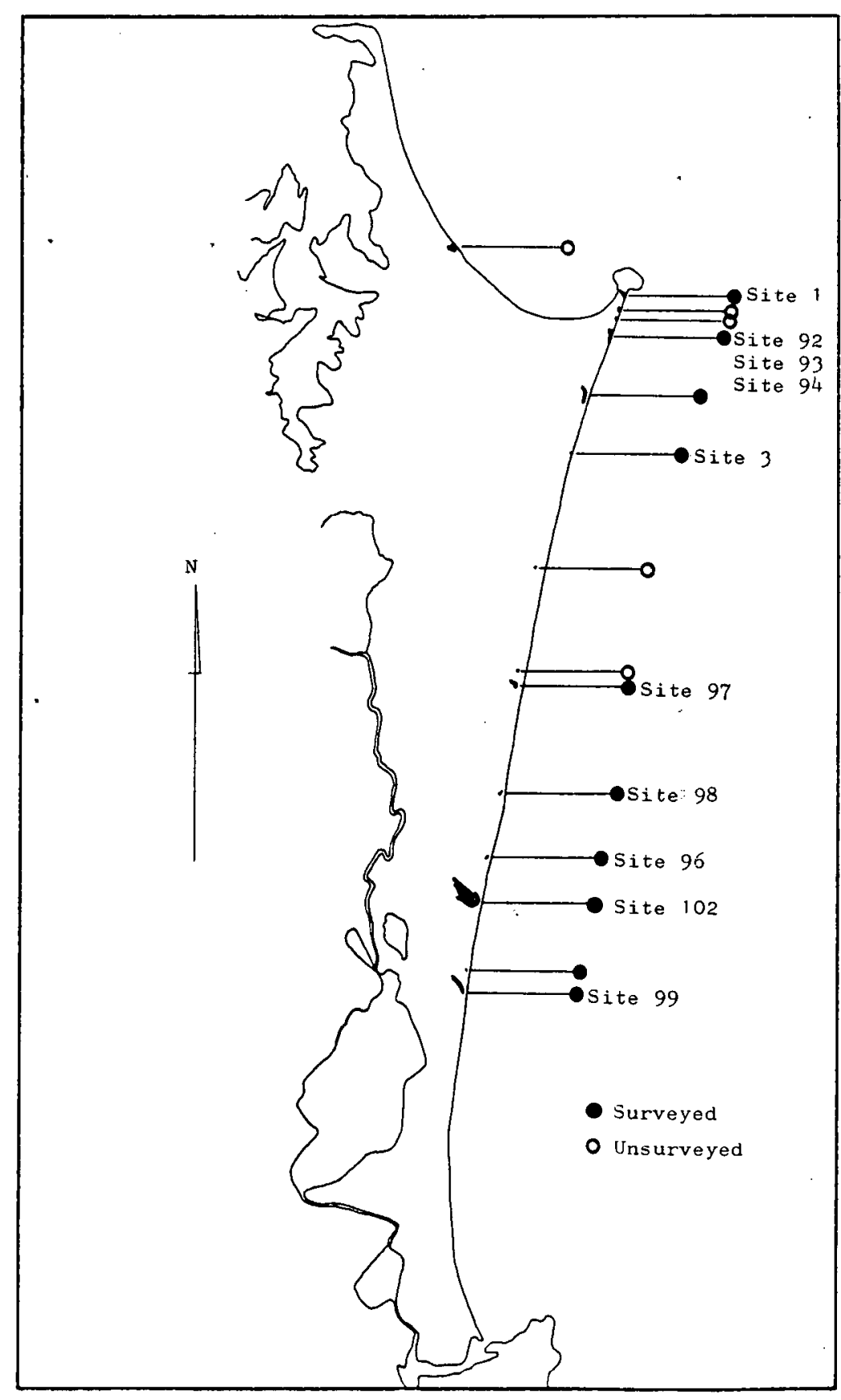

Figure 10. Surveyed and unsurveyed sandblows in the Cooloola Region.

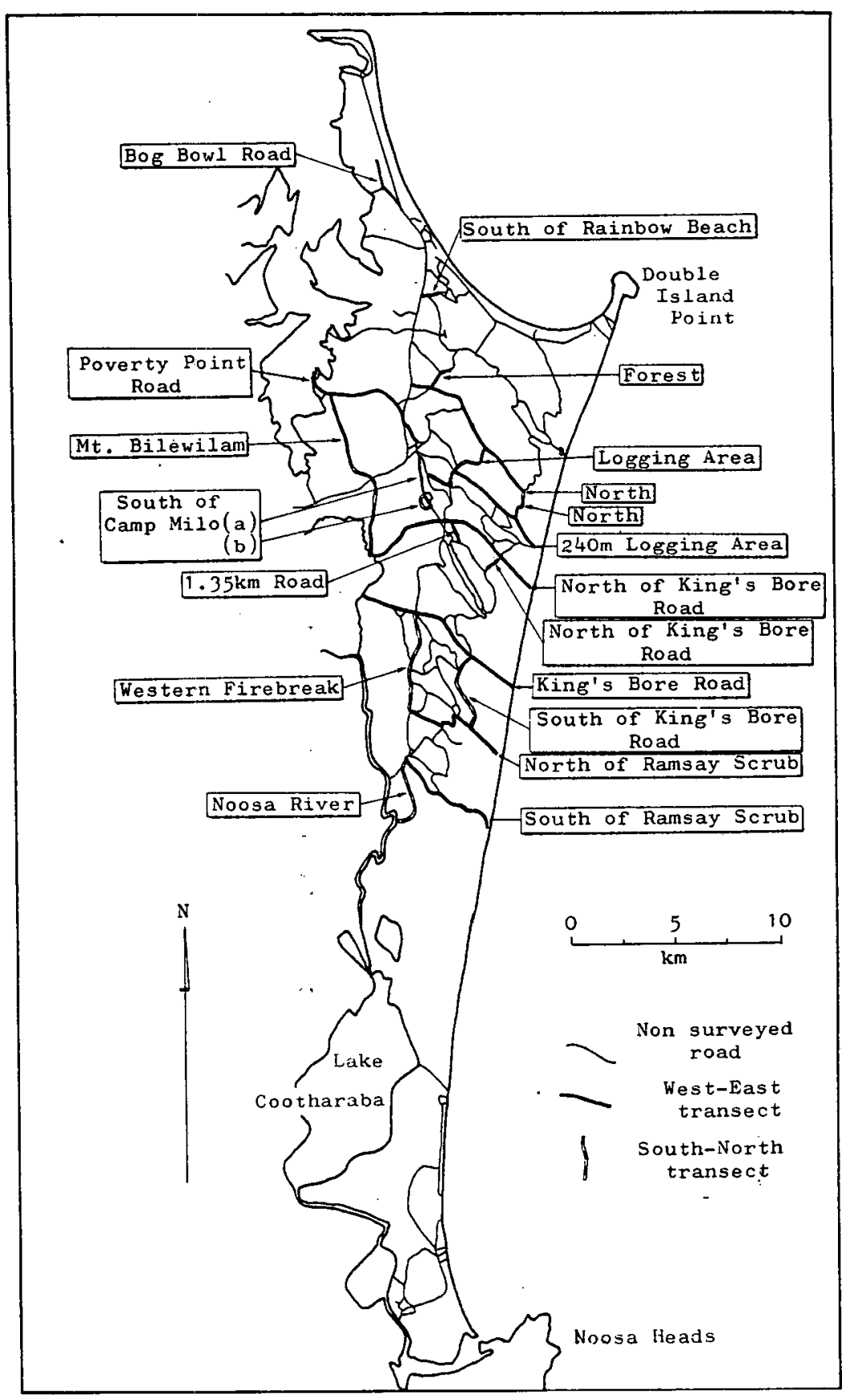

Figure 11. Sandtrack transects in the Cooloola survey area. 
Transects were apportioned according to soil landscape type and observed and expected shell fragment abundance within each portion were compared using Chi-square analysis. Expected shell abundance figures were calculated by multiplying the relative proportion of each soil landscape type of the entire transect by the total number of shell fragments found along that transect. Al1 Chi-square values demonstrate a non-random distribution of shell along transects.

The difference between the observed and expected number of shell fragments in each soil landscape portion of transect was compared for all transects to ascertain whether shell was biased to certain soil landscape types. No consistent association was found to exist. The inconsistency of the gross soil landscape association test was overcome when an analytical threshold of 10 shell fragments per transect metre was employed. The number of observed and expected transect metres with 10-49 shell fragments and $>49$ shell fragments within each soil landscape was compared using Chi-square analysis. Results demonstrate a bias towards the $>49$ shell fragment group to the MD, $M$ and especially IP soil landscapes, and a bias towards the 10-49 shell fragment group to the W, $M$ and once again especially IP soil landscapes (Figure 12).

Observed and expected frequencies of the number of transect metres (W-E transects on $1 y$ ) with $1,2,3 . .049$ shell fragments within each soil landscape were compared using Poisson relative expected random frequencies and Chi-square analysis. The results demonstrate a non random distribution of too many metres of transect with no shell (randomness $P=<0.005$ ) suggesting shell fragments exhibit a clumped distribution along transects.
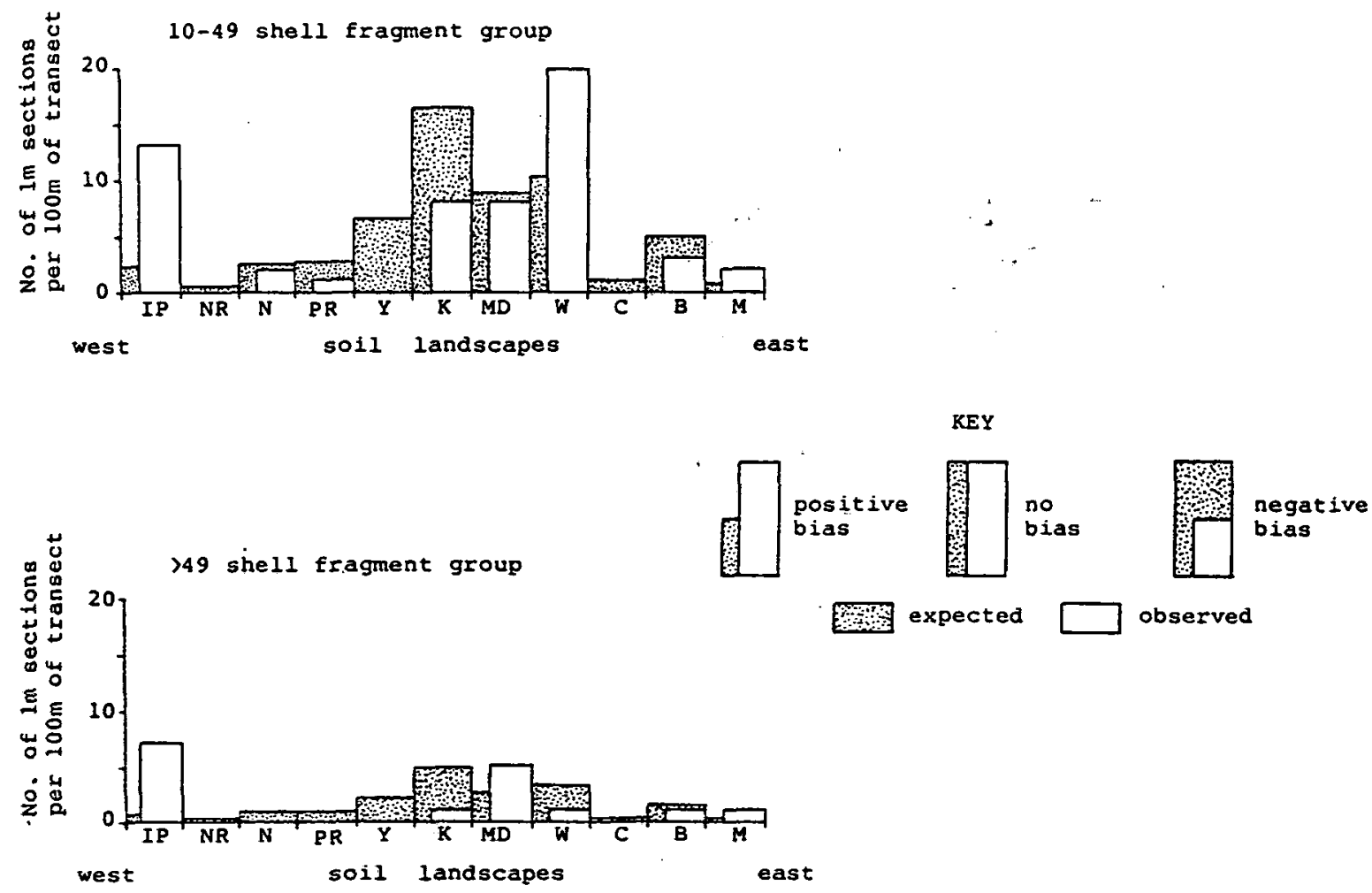

Figure 12. Observed and expected shell fragment density groups for $100 \mathrm{~m}$ sections of sandtrack transects within soil landscapes across the Cooloola survey area. 
At least six different shell species were observed, four of which were identified as either pipi, oyster, cockle or whelk shell. Estuarine and oceanic shells were transported up to $12 \mathrm{~km}$ and $8 \mathrm{~km}$ inland (respectively) from their nearest possible source. Interestingly, a large longitudinal zone of overlap exists for the two major shell types towards the centre of the sandmass (Figure 13).

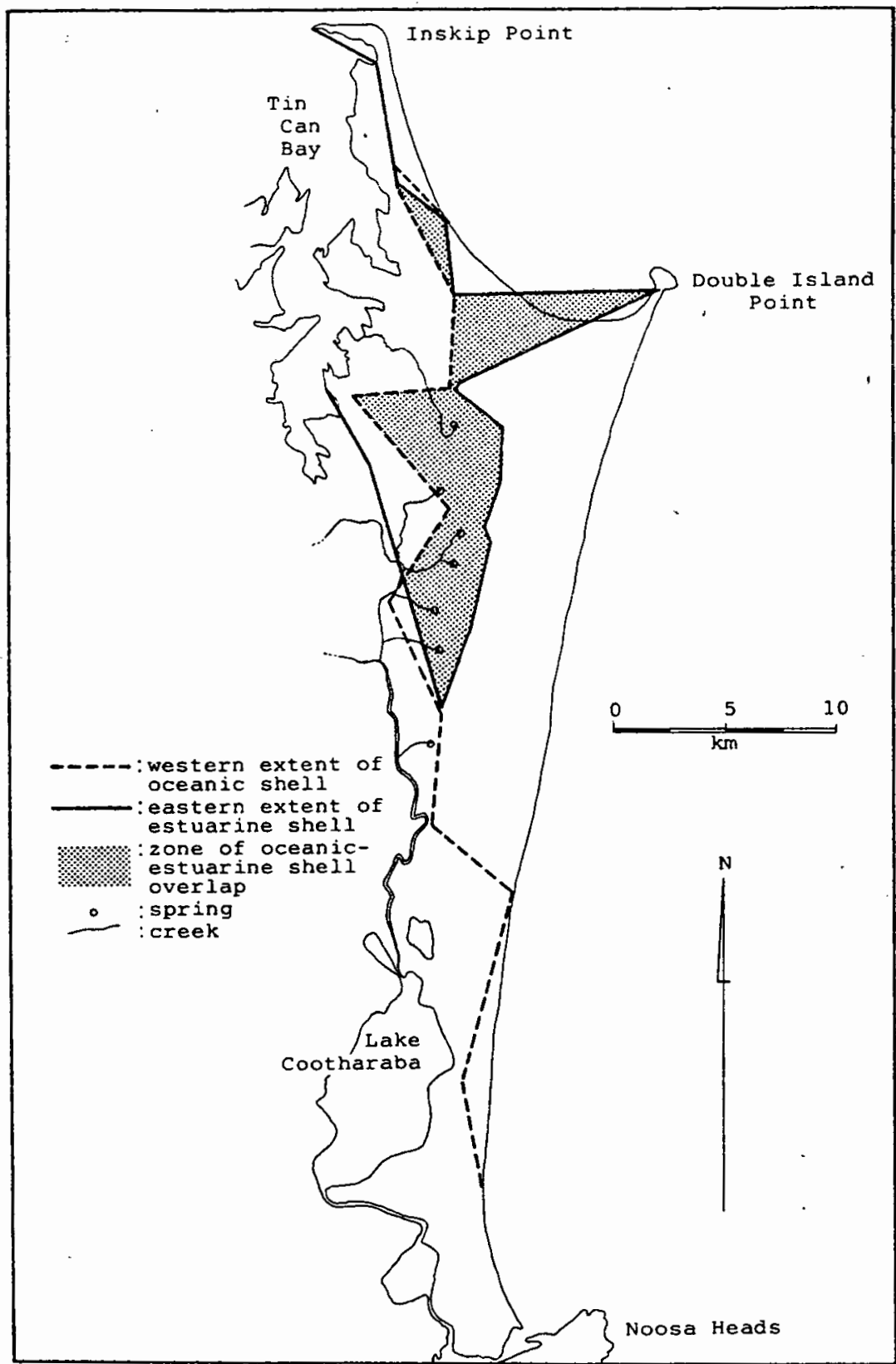

Figure 13. Maximum inland extent of estaurine and oceanic shell in the survey area. 
The relative significance of each shell species for each kilometre of transect clearly demonstrates the the decreasing significance of estuarine shell species as one moves away from Tin Can Bay (Figure 14). of the 53 one-kilometre transect portions with shell fragments, 34 $(64.2 \%)$ have pipi shell fragments only, whilst only $2(3.8 \%)$ have estuarine shell fragments only. It is interesting that the two transect portions with cockle as the most significant estuarine shell specie (ie. Bog Bow 1 Road S-N transect and Poverty Point W-E transect) are the closest of all transect portions to Tin Can Bay. Furthermore, the transect portions with estuarine shell farthest away from Tin Can Bay evidence no cockle shell at all (eg. South of Camp Milo S-N transects).

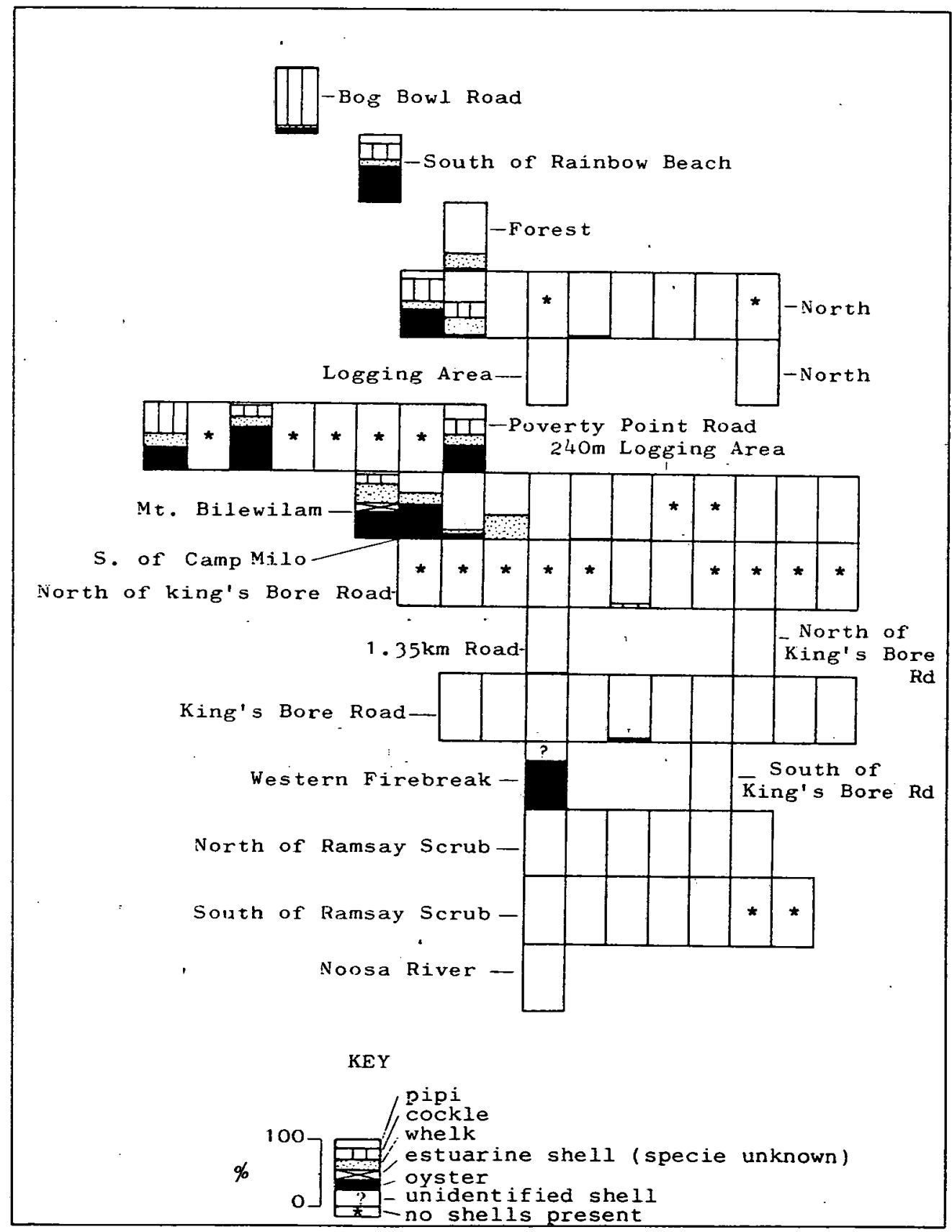

Figure 14. Relative proportions of differing shell species for $1 \mathrm{~km}$ sections of sandtrack transects. 
Differential shell fragmentation both between differing species and along different sections of transect as well as differential visibility along transects could have biased the survey results. In an attempt to assess the effects of differential shell fragmentation, a sample of freshly eroded shell from site 82 was analyzed and compared to the findings for the first $50 \mathrm{~m}$ of the Poverty Point W-E transect commencing some $50 \mathrm{~m}$ away. Wave action had removed the sandy matrix surrounding the in situ shells at site 82 depositing the shell residue on the sandflats. A $1 \mathrm{~m} \times 1 \mathrm{~m}$ section of this shell residue was analyzed and the relative frequencies of oyster, cockle and whelk shells assessed. The resuits show that whilst the relative proportions of cockle shell in both areas are similar, large differences exist for whelk and oyster shells (Figure 15). Whelks are only half as significant along the transect compared to the test square, whilst for oysters the situation is reversed. All factors being equal, the results suggest differential shell fragmentation may distort assessment of the relative significance of shell species along transects.

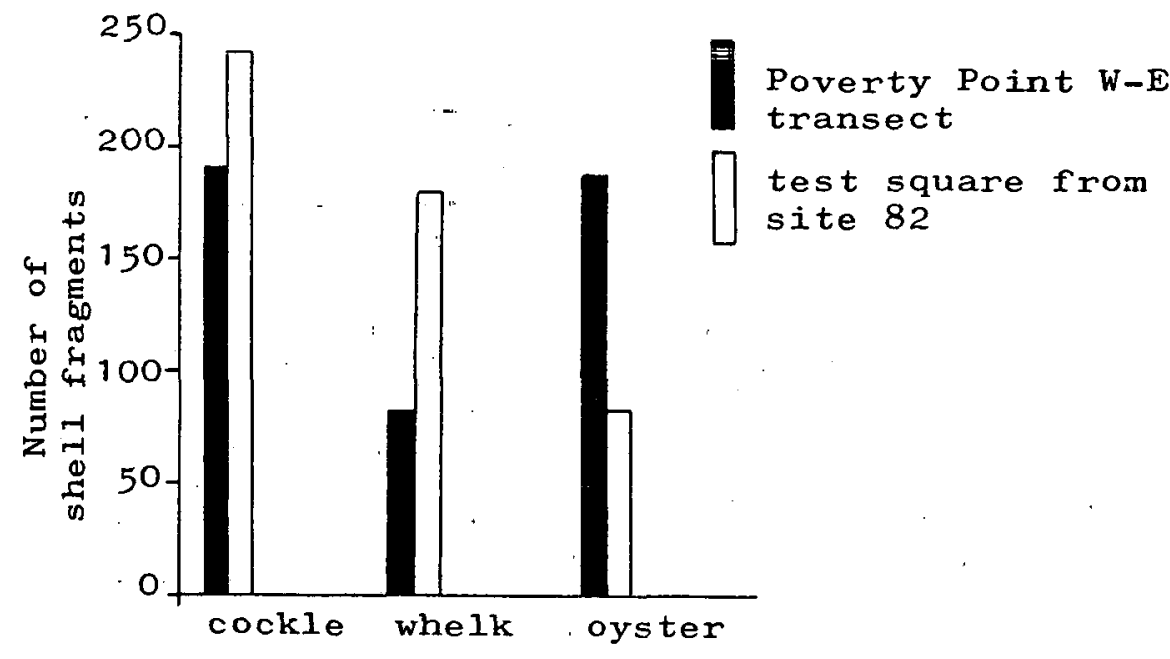

Figure 15. Relative proportions of differing shell species for test square at Site 82 and the first $50 \mathrm{~m}$ of Poverty Point W-E transect.

It would be premature to apply a correction formula to all transect shell fragment recordings based on this small test for the following reasons. Firstly, differential shell fragmentation may also characterize the test square shell sample. Secondly, although shell distribution between the two samples appeared to be continuous, differing relative shell frequencies over the distance may already exist. Thirdly, shell fragmentation processes along all transects may not be uniform. Therefore, resolution of the differential shell fragmentation problem awaits further study.

Visibility along transects ranged from almost $100 \%$ (eg. Mt. Bilewilam S-N transect) to $20-30 \%$ (eg. $1.35 \mathrm{~km}$ Road transect) with the majority exhibiting over $50 \%$. Given that the majority of transect portions exhibiting the extremes of visibility evidenced few shell, fragments, it is probable that visibility had little biasing effect upon the survey results. 


\section{Stone Artefacts}

Rav material: Although only two major types of stone are found within the survey area (ie. andesite and sandstone), 15 stone artefact raw materials were recorded (Table 4). Four of these, andesite, silcrete, sandstone and quartz constitute. $85 \%$ of all stone materials with silcrete predominating, constituting $34.2 \%$ of all stone artefacts. The location of andesite at the northeast corner of the study area (Double Island Point) and isolated outcrops of sandstone to the south of the study area suggests differential use of these raw materials might be correlated.with the latitude of sites along Teewah Beach and $T$ in $C$ an Bay, sites within sandblows and artefacts recorded along the sandtrack transects. For comparison relative use of silcrete was included. For most of the areas the results are very similar, with andesite the predominate raw material in the north, and silcrete and sandstone predominating in the south (Figures 16, 17, 18 and 19).

Table 4. Stone artefact raw materials from Cooloola . survey area.

\begin{tabular}{lrr}
\hline RAW MATERIAL" & NUMBER & PERCENTAGE \\
\hline Andesite & 144 & 19.75 \\
Silcrete & 249 & 34.16 \\
Sandstone & 100 & 13.72 \\
Quartzite & 25 & 3.43 \\
Quartz & 133 & 18.24 \\
Chert & 18 & 2.47 \\
Chalcedony &. .3 & 0.41 \\
Mudstone & 9 & 1.23 \\
Silicified Mudstone & 8 & 1.10 \\
"Basalt" & 10 & 1.37 \\
"Volcanic" & 4 & 0.55 \\
Ocherous Sandstone & 4 & 0.55 \\
Quartz conglomerate & 9 & 1.23 \\
Iron-stone & 3 & 0.41 \\
Unidentified & 10 & 1.37 \\
& & \\
\hline Totals: & 729 & 100.00
\end{tabular}

Stone artefact types: Seven stone artefact types were'recorded during the survey. Five of the types have already been described. The remaining two are a backed blade and small quartz pebbles which possibly represent the more resistant and less weathered remains of sandstone artefacts whose softer matrix has been eroded away (c. Thompson pers. comm.). The two dominate artefact types are flakes and manuports (Table 5).

Silcrete is the most significant raw material type for flakes $(60.4 \%)$, cores $(67.9 \%)$ and flaked pieces (57.2\%). Interestingly, andesite is the next most significant raw material for knapping. Sandstone is the dominate material constituting manuports ( $41.5 \%)$, andesite constituted all 'bevelled pounders' and most pebbles were quartz (95.2\%) (Table 6). 
Table 5. Relative proportions of stone artefact types in survey sub-areas and for the Cooloola survey generally.

\begin{tabular}{|c|c|c|c|c|c|c|c|}
\hline $\begin{array}{l}\text { Survey } \\
\text { sub-area }\end{array}$ & & 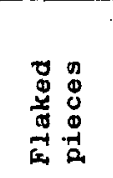 & $\begin{array}{l}n \\
0 \\
0 \\
0 \\
0 \\
0\end{array}$ & 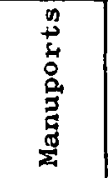 & $\begin{array}{l}0 \\
0 \\
0 \\
0 \\
0 \\
0 \\
0 .\end{array}$ & 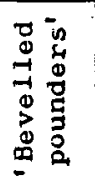 & 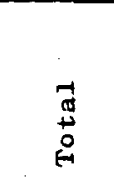 \\
\hline \multirow[t]{2}{*}{ Teewah Beach } & 18 & 8 & 2 & 23 & 0 & 0 & 51 \\
\hline & 35.29 & 15.68 & 3.92 & 45.10 & 0.00 & 0.00 & 100.00 \\
\hline \multirow[t]{2}{*}{ Sandblows } & 68 & 76 & 12 & 135 & 103 & 0 & 394 \\
\hline & 17.26 & 19.29 & 3.05 & 34.26 & 26.14 & 0.00 & 100.00 \\
\hline \multirow{2}{*}{$\begin{array}{l}\text { Inland(incl. } \\
\text { Lake Poona) }\end{array}$} & 58 & 30 & 2 & 27 & 0 & 0 & 117 \\
\hline & 49.57 & 25.64 & 1.71 & 23.08 & 0.00 & 0.00 & 100.00 \\
\hline \multirow[t]{2}{*}{ Tin Can Bay } & 73 & 45 & 12 & 32 & 0 & 5 & 167 \\
\hline & 43.71 & 26.95 & 7.19 & 19.16 & 0.00 & 2.99 & 100.00 \\
\hline \multirow[t]{2}{*}{ Overall } & 217 & 159 & 28 & 217 & 103 & 5 & 729 \\
\hline & 29.77 & 21.81 & 3.84 & 29.77 & 14.13 & 0.69 & 100.00 \\
\hline
\end{tabular}

Table 6. Relative proportions of raw materials for differing stone artefact types.

\begin{tabular}{|c|c|c|c|c|c|c|c|c|c|c|c|c|}
\hline $\begin{array}{l}\text { Raw } \\
\text { material }\end{array}$ & $\begin{array}{r}\text { Manu } \\
\mathbf{n}\end{array}$ & $\begin{array}{c}\text { aports } \\
\%\end{array}$ & & $\begin{array}{c}\text { Laked } \\
\text { Leces } \\
\% \\
\end{array}$ & n! & $\begin{array}{l}\text { Cores } \\
\%\end{array}$ & $\mathbf{n}$ & $\begin{array}{l}\text { kess } \\
\%\end{array}$ & $\begin{array}{l}\mathbf{P e} \\
\mathbf{n}\end{array}$ & $\begin{array}{c}\text { b1es } \\
\%\end{array}$ & & $\begin{array}{c}\text { evelled } \\
\text { unders } \\
\%\end{array}$ \\
\hline Andesite & 57 & 26.27 & 39 & 24.53 & 3 & 10.71 & 38 & 17.51 & 2 & 1.94 & 5 & 100.00 \\
\hline Silcrete & 7 & 3.23 & 91 & 57.23 & 19 & 67.86 & 131 & $60 \cdot 37$ & 1 & 0.97 & o & 0.00 \\
\hline Sandstone & 90 & 41.47 & 2 & 1.26 & 2 & $7 \cdot 14$ & 6 & 2.76 & o & 0.00 & o & 0.00 \\
\hline Quartzite & 6 & 2.76 & 4 & 2.52 & 1 & 3.57 & 14 & 6.45 & o & 0.00 & o & 0.00 \\
\hline Quartz & 18 & 8.29 & 13 & 8.18 & o & 0.00 & 4 & 1.84 & 98 & 95.15 & o & 0.00 \\
\hline Chert & 4 & 1.84 & 4 & 2.52 & 1 & 3.57 & 9 & 4.15 & o & 0.00 & 0 & 0.00 \\
\hline Chalcedony & o & 0.00 & 3 & 1.89 & o & 0.00 & 0 & 0.00 & o & 0.00 & 0 & 0.00 \\
\hline Muds tone & 7 & 3.23 & 0 & 0.00 & 0 & 0.00 & 2 & 0.92 & o & 0.00 & $\mathbf{o}$ & 0.00 \\
\hline $\begin{array}{l}\text { Silicified } \\
\text { mudstone }\end{array}$ & 3 & 1.38 & 0 & 0.00 & o & 0.00 & 5 & 2.30 & o & 0.00 & 0 & 0.00 \\
\hline 'Basalt' & 2 & 0.92 & 3 & 1.89 & 1 & 3.57 & 4 & 1.84 & o & 0.00 & 0 & 0.00 \\
\hline 'Volcanic' & 2 & 0.92 & 0 & 0.00 & 1 & $3 \cdot 57$ & 1 & 0.46 & o & 0.00 & o & 0.00 \\
\hline $\begin{array}{l}\text { Ochreous } \\
\text { sands tone }\end{array}$ & 4 & 1.84 & o & 0.00 & o & 0.00 & o & 0.00 & o & 0.00 & o & 0.00 \\
\hline $\begin{array}{l}\text { Quartz } \\
\text { conglomerate }\end{array}$ & 6 & 2.76 & o & 0.00 & 0 & 0.00 & 2 & 0.92 & 1 & 0.97 & o & 0.00 \\
\hline Iron'stone & 3 & 1.38 & 0 & 0.00 & 0 & 0.00 & 0 & 0.00 & 0 & 0.00 & 0 & 0.00 \\
\hline Unknown & 8 & 3.69 & 0 & 0.00 & o & 0.00 & 1 & 0.46 & 1 & 0.97 & o & 0.00 \\
\hline Totals: & 217 & 100 & 159 & 100 & 28 & 100 & 217 & 100 & 103 & 100 & 5 & 100 \\
\hline
\end{tabular}




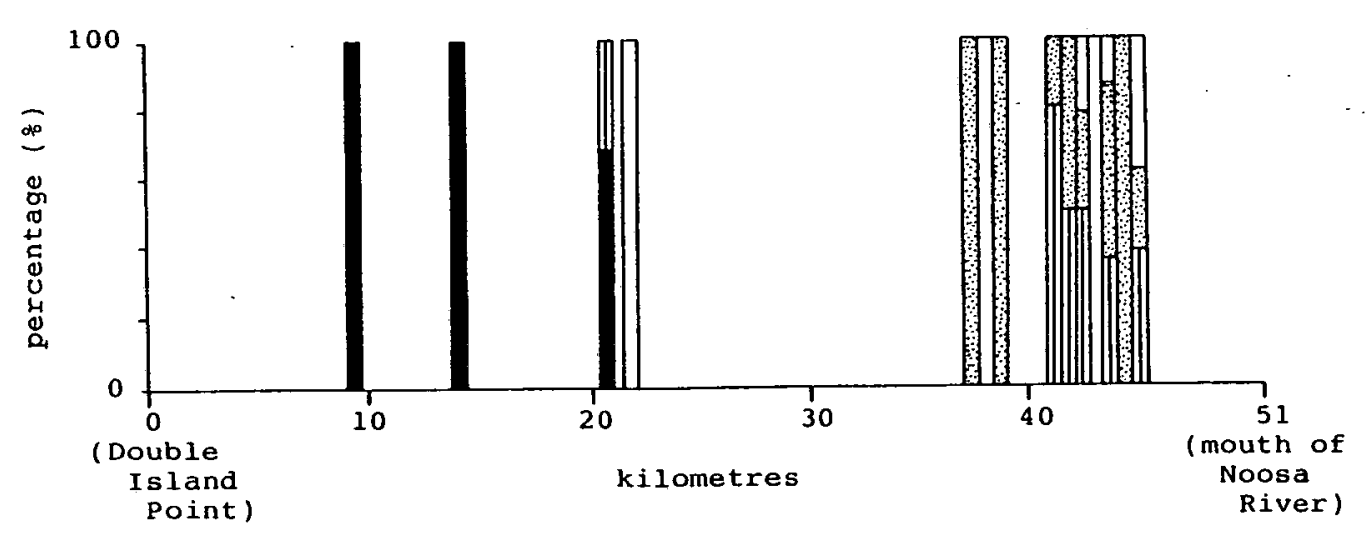

andesite sandstone

Figure 16. Relative proportions of selected stone artefact raw materials on Teewah Beach sites.

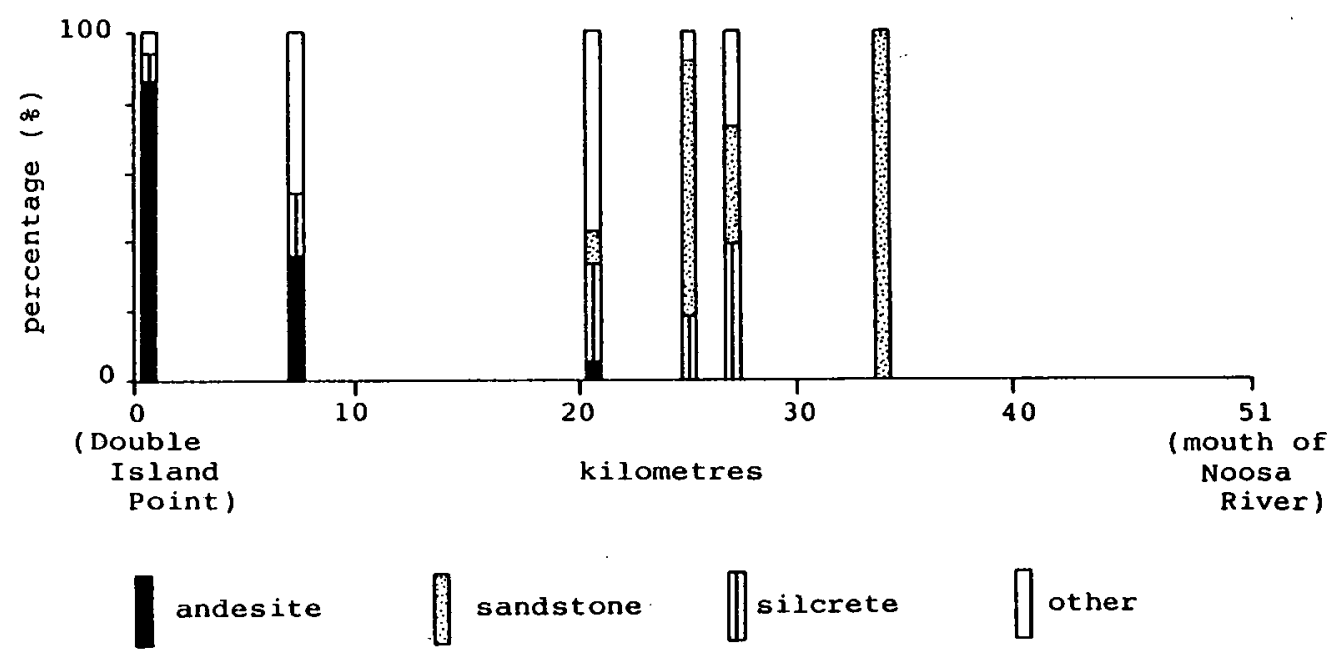

Figure 17. Relative proportions of selected stone artefact raw materials on sandblow sites.

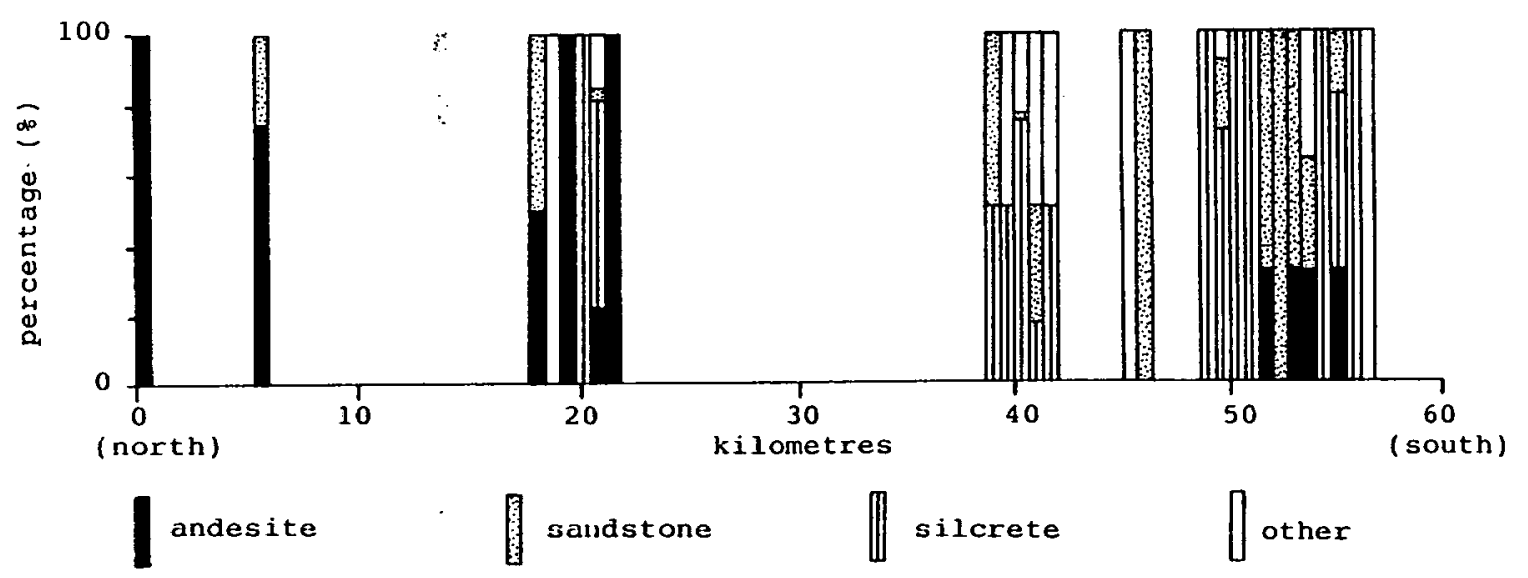

Figure 18. Relative proportions of selected stone artefact raw materials on Tin Can Bay sites. 
Stone artefact size: The following analyses were performed to assess patterns in artefact sizes occurring relative to proximity to Double Island Point.

The trend in variables recorded for silcrete flakes from Teewah Beach and sandblow sites suggests larger measurements southwards (Figure 20). Comparing silcrete to andesite flakes results in an opposite trend with flake measurements decreasing southwards (Figure 21 ). similar measurement trends are seen in andesite flaked pieces. The change in volume of sandstone manuports suggests a decreasing trend southwards. Too few cores were recorded for valid statistical analysis.

Secondary artefact working: Thirty-eight artefacts evidenced signs of use-smoothing and/or retouch. Nearly all artefacts with 'ground' facets were manuports $(92.3 \%)$, with most being constituted by sandstone (76.9\%). Artefacts with glossed edges mostly occur on andesite $(77.8 \%)$, with 'bevelled pounders' the predominate artefact type (88.9\%). Knapped silcrete artefacts (flakes, flaked pieces and cores) constitute the major artefacts upon which retouch, and retouch and use-gloss occur. Most of the artefacts with retouch and use-gloss occur in the vicinity of the estuarine coastline.

\section{DISCUSSION}

\section{Sandblow sites}

The sandblows on the Cooloola sandmass and Fraser Island are similar regarding location and type of archaeological materials exhibited. Lauer (1979:55-56) investigated the "curious location" of stone artefact scatters on Fraser Is land sandblows in a context of "open unvegetated and loose sand, completely at the mercy of the elements". Lauer suggests an anthropogenetic origin for the sandblows resulting from normal daily activities around camp sites (eg. firewood collection). Evidence from Cooloola suggests an alternative hypothesis.

Thompson (1983) in a discussion of parabolic sand dunes of the subtropical Australian east coast, states sandblows bury vegetation and sand dunes in their path, subsequently re-exposing them when the dune apex has advanced further inland. This exposed dune floor can be cut below the original dune surface exposing the remains of tree roots and freshwater sources from interception of a watertable (Thompson 1983:210211). It has already been stated that vegetation and/or soil disturbance istrequired to expose artefacts in the survey area. Therefore, if a sandblow and stone artefact scatter intersect, the latter may be exposed on the deflated remains of the original dune surface as "lag gravels" (Thompson and Moore 1984:79), after the original sandblow apex has moved further inland. This can result in the coexistence of reexposed artefacts and freshwater sources, an association without a human behavioural causal connection.

Two areas of evidence support the sandblow exposure hypothes is. The first is the existence of two sandblows devoid of archaeological materials, and the very large sandblow (120,000 square metres) containing only two artefacts (site 99). The second is the existence of a large number of artefacts precariously positioned on the steep internal slopes of trailing arms of many sandblows (eg. sites 96 and 97), and the sectioned old dune surface containing cultural material at site 1. 


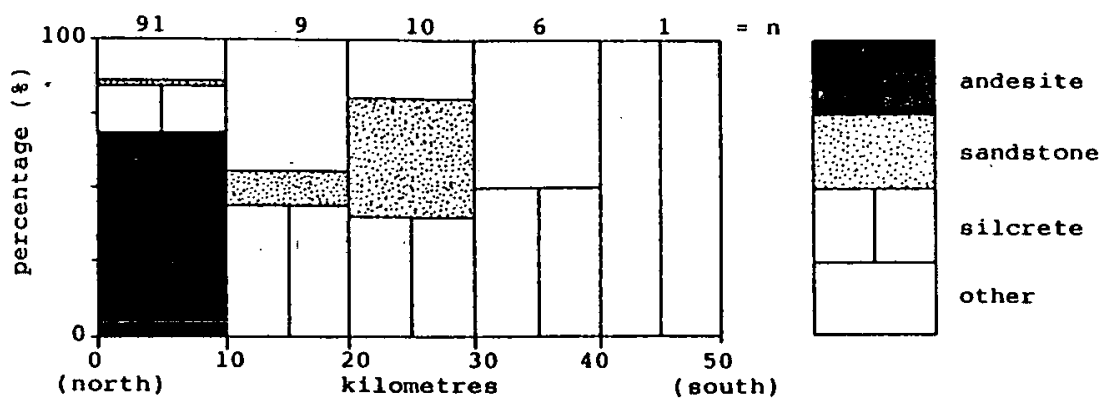

Figure 19. Relative proportions of stone artefact raw materials for $10 \mathrm{~km}$ sections of the inland (sandtrack transects and Lake Poona) survey sub-area.

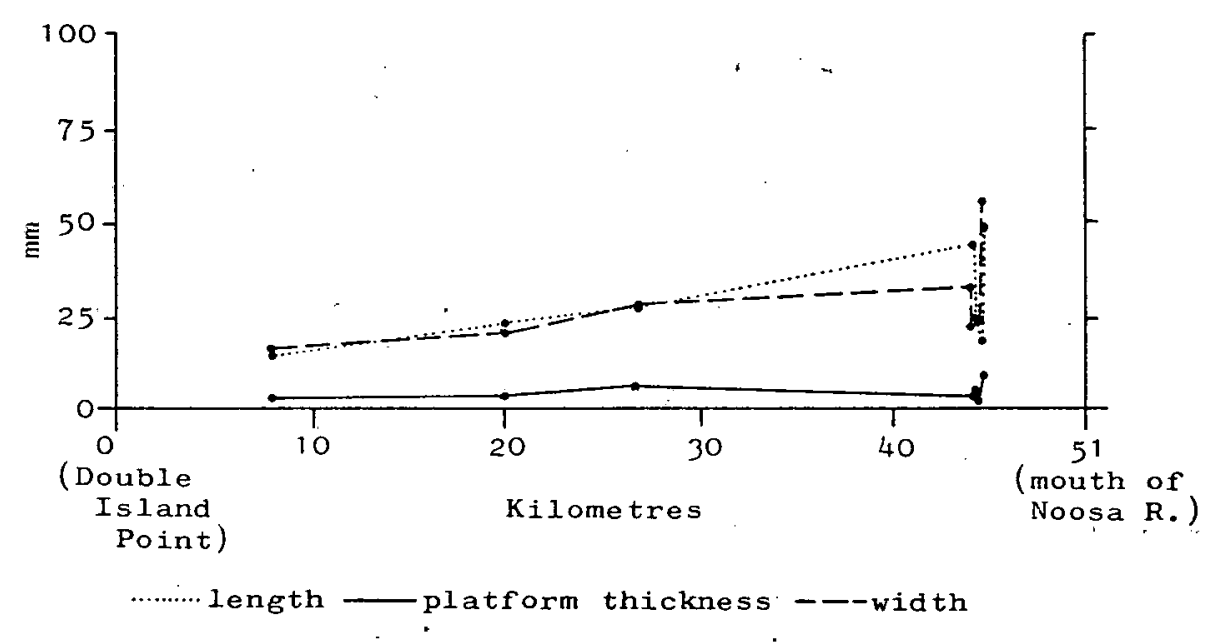

Figure 20. Latitudinal change in silcrete flake variables for Teewah Beach and sand-. blow sites.

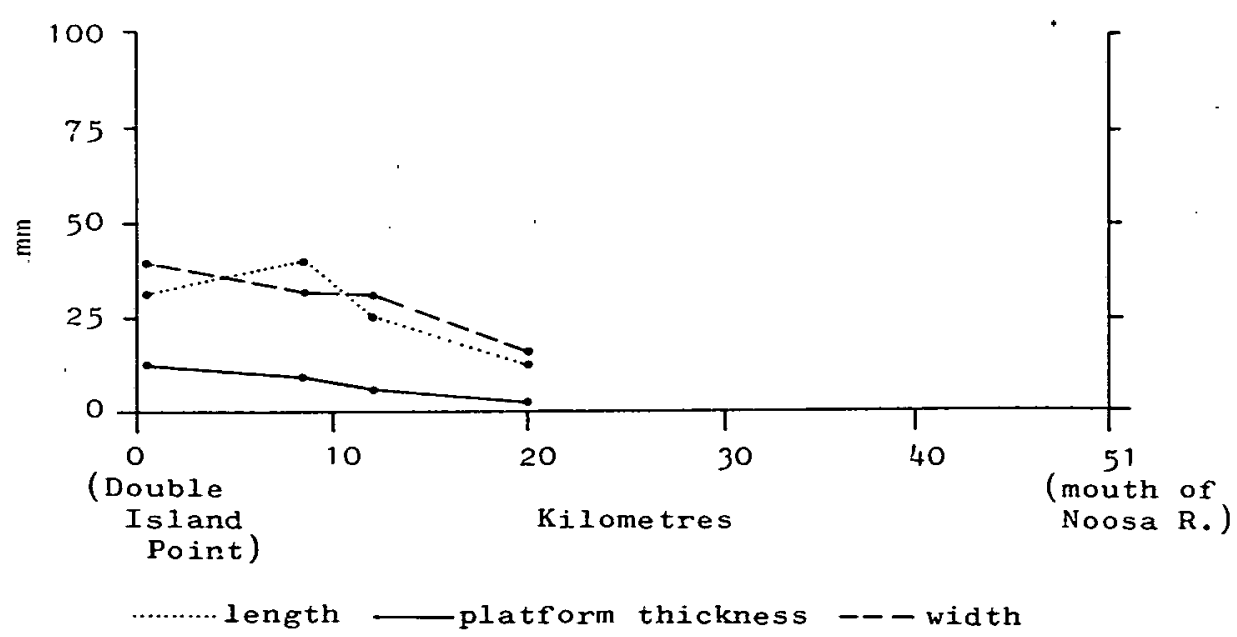

Figure 21. Latitudinal change in andesite flake variables for Teewah Beach and sandblow sites. 
The lack of faunal materials on most sandblow sites suggests that they either never existed or that all had disappeared due to weathering processes. The latter option suggests two alternative hypotheses. First, prolonged exposure of faunal materials to sandblasting on the present sandblow surface or on even older sandblow surfaces has weathered the less resistant organics away. Evidence of sand glossed artefacts and pebbles eroding from trailing arms of sandblows would confirm recycling. Second, prior to incorporation into a sandblow, faunal materials were chemically weathered away.

\section{IP soil landscape bias and comparisons with Bribie Is1and}

The IP soil landscape (strand plain) evidenced the greatest bias of shell fragments during this survey (ie. Bog Bowl Road S-N transect). This may reflect the transects unique close proximity to the two marine resource zones (ie. estuarine and oceanic). However, of the over 12,000 shell fragments recorded along the transect running equidistant between the two coasts, only $1 \%$ are oceanic she11 (ie. pipi). obviously people are not positioning themselves optimally to equally exploit shellfish from both coasts. The nearby existence of shell middens on the adjacent estuarine shore suggests either seasonal 'inland' sites, intra-group dichotomization in subsistence activities or elements of temporally discrete settlement-subsistence systems.

Bribie Island and the strand plain physiographic unit of the Cooloola Region are environmentally analogous. Interestingly, in both areas east coast contexts evidence little archaeological material. Such a situation is atypical of other high energy coastal contexts in southeast Queensland. This suggests either lack of use or erosion of once extant 'sites'. The latter has been hypothesized for Bribie Island (J. Ha11 pers. comm. 1982).

Vegetation zonation immediately inland from the beach is a useful indicator of past coastal erosion (McKenzie 1980, 1985). The forest and woodland communities fringing the coastline north of Rainbow Beach suggests severe coastal erosion has taken place in the past (see Thompson and Moore 1984:14). Consequently, the present coastline represents a cross-section of non-coastal land when only Aborigines inhabited the area. Aboriginal use of the coastline may never be directly ascertained archaeologically.

\section{Vineforest exploitation?}

The inland environments of Moreton Island and Fraser Island yield little evidence of intensive exploitation by hunter-gatherers. In fact the inland sites on Moreton Island are characterized as being only "temporary", "dinner" or "transit" camps (Robins and Hal1 1981:10, Hall and Robins 1984). The density and areal extent of shell fragments along many of the inland sandmass sandtrack transects at Cooloola suggests more intensive exploitation.

Shell fragments located inland on the Cooloola sandmass are numerically biased to the MD and $W$ soil landscapes. The $W$ soil landscape supports vineforest and tall blackbutt forest. No vineforest exists on Moreton Island, however it forms a central corridor along with blackbutt forest on Fraser Island (Dowling and MacDonald 1976, Devitt 1979, Thompson and Moore 1984). The paucity of large inland sites on Moreton Island and the incomplete inland survey of Fraser Island away from sandblows (Lauer 1979) raises the question whether the relatively larger inland 'sites' at Cooloola are related to vineforest exploitation. 
Information, on Aboriginal use of vineforests suggests both occupation and exploitation occurred (Campbel1 1982, Bowdler 1983, Lourandos 1983, Horsfall 1984). The main implication of the vineforest exploitation hypothesis at Cooloola is that the vineforest areas contain relatively more food resources than other areas. In fact, present evidence suggests this may be the case.

Cycads and fern roots have been well documented as Aboriginal plant foods in coastal southeast Queensland, even to staple status (Devitt 1979, Gillieson and Hall 1982, see also Beaton 1977). Two species of cycad are found on the Cooloola sandmass. Macrozamia pauli-guilielmi is ubiquitous, whilst Macrozamia miquelli is mainly restricted to the W soil landscape (McDonald and Thompson 1981:51, C. Thompson pers. comm.) and characterized as a "common understorey plant" in vineforests (Webb and Tracey 1975:320). Although the fern root 'bungwall' (Ble indicum ) is sporadically distributed on coastal sandplains, on the sandmass it is mainly restricted to vineforests where it is "common" (Webb and Tracey 1975:320).

Regarding potential faunal resources, vineforests exhibit the highest mammal abundance rating for any vegetation zone at Cooloola (eg. most phalangerines, ringtails and bats occur in vineforest and/or tall blackbutt forest). Although vineforests display the lowest diversity of terrestrial birds, the surrounding tall blackbutt forest contains the greatest diversity and abundance (Gravatt and Ingram 1975, Roberts and Ingram 1976 Dwyer, Hockings and Willmer 1979, Dwyer, Kikkawa and Ingram 1979). Therefore, the $W$ soil landscape appears to contain relatively more potentially significant resources than other sandmass areas. It is probable that people took advantage of this suggested resource concentration.

An ironical twist to the vineforest exploitation hypothesis is that all shell fragments found within the $W$ soil landscape are located outside the vineforest in the surrounding blackbutt forest. This situation may simply be related to comfort. Inside the vineforest the environment is moist and dark, insects are manifest in the profuse leaf litter and the underbrush is very dense. In contrast, the blackbutt forest is usually situated on higher ridge slopes and crests with relatively open underbrush in moderate sunshine.

\section{Western sandmass shell bias}

The $W$ soil landscape is flanked to the west and east by the MD, and $B$ and $C$ soil landscapes respectively. Only the MD soil landscape yielded substantial quantities of shell fragments. Present evidence does not suggest any major food resource concentrations within the MD soil landscape. However, it is interesting to note the existence of a small number of rainforest pockets west of the $W$ soil landscape; two of which have transects adjacent to them. Shell fragments in the $R$ and $M D$ sections of these transects are concentrated near the vineforest pockets. Whether 'sites' located in the MD and $\mathrm{K}$ soil landscapes represent localized, small-scale vineforest exploitation remains to be seen. The location of most springs and creeks on the western side of the sandmass may also have 'site' location significance. The location of nearly all these major springs within the zone of overlap between the inland extent of oceanic and estuarine shell certainly is suggestive of some causality (see Figure 11). 


\section{Mundu soil landscape shell bias}

The biasing of shell fragments to the $M$ soil landscape flanking much of the oceanic coastline suggests comparisons with Teewah Beach midden sites. The lack of terrestrial faunal remains in archaeological contexts in these areas suggests a marine orientation for dietary protein. Such a situation is interesting given the Banksia and E.signata woodlands flanking the $M$ soil landscape possess the highest mammal diversity rating for the sandmass (Dwyer, Hockings and Wi11mer 1979). Whether this apparent marine orientation truely. reflects behaviour,. or is a distortion due to differential preservation or surface visibility can be tested through excavation.

The apparent locational bias of Teewah Beach sites to pandanus trees and the suggested causal association is not altogether surprising. Pandanus is well documented as of nutritional significance to Aborigines (Worse1y 1961, Golson 1971, Meehan, Gaffey and Jones 1979, Meehan 1980), with specific ethnohistorical reference to its consumption in Moreton Bay and Fraser Island (Devitt 1979, Petrie 1980, see also Hall 1980). Whether the apparent association of middens and pandanus trees along Teewah Beach has direct behavioural causality (ie. shelter and/or food exploitation) or is the result of pandanus seeds in middens germinating and developing into trees remains to be seen.

\section{Coastal versus inland}

Both archaeological and ethnohistorical evidence from Moreton Bay and Fraser Island suggests settlement and subsistence concentrated along the coastal fringes (Devitt 1979, Hall 1982a). Shell fragment distributions at Cooloola suggest people were moving at least $12 \mathrm{~km}$ inland. It is tempting to suggest a seasonal dichotomy in subsistence. However, the inland extent of shellfish remains is comparable to home base exploitation radii observed in ethnographic situations (Lee 1969:61, Roper 1979:121). Whether coastal and interior 'sites' represent homebases occupied for long periods and satellite, resource specific exploitation loci of short duration respectively has yet to be ascertained (see Bettinger 1980:198-199, Foley 1981:5). These two extremes of subsistence behaviour when coupled with the variability in archaeological materials across the entire survey area suggests a rather complex model may be required to explain Aboriginal environmental articulation at Cooloola.

\section{Stone artefacts}

The availability of only two stone artefact raw material sources in the study area produced a number of patterns similar to those found in other contexts in southeast Queensland.

It has become well known that the physical properties of available rock and the desired functions for stone artefacts are two major variables affecting raw material use. Preliminary analysis of artefacts at Cooloola certainly demonstrates this interaction with the more desirable knapping qualities of many siliceous rocks (eg. chalcedony, chert, quartzite) being surpassed by the less desirable, though more accessible qualities of andesite. The limitations of artefact raw material availability obviously were exceeded by the functional requirements of stone artefacts. In fact over $65 \%$ of a 11 raw materials were imported from beyond the region. Lauer (1979:66) found a similar situation on 
Fraser Island where the two local rock types constitute only "11.1\% of all recovered artefacts".

The trend towards larger artefacts closer to probable raw material source was clearly seen in the proximity of andesite artefacts to Double Island Point. Such trends have been interpreted as a function of diminishing resource availability away from raw material source (see Byrne 1980). Although Godwin (1982) suggests this simplistic model may be complicated by differing artefact functions and discard patterns away from the raw material source, such a behavioural spoiler may be inconsequential at Cooloola given given the relatively smooth gradients for artefact sizes as one moves away from assumed raw material sources. Both Double Island Point (Cooloola) and Cape Moreton (Moreton Island) are rocky headlands located on the northeast of a big sandmass. Interestingly, andesite manuports dominate sites in close proximity to the headland in both areas. Godwin (1982:65), following an earlier hypothesis by J. Hall (1982b), suggests that for Moreton Island these sites "appear to be primarily associated with stone procurement and artefact manufacture, with only limited exploitation of available resources". The vast number of andesite manuports at site 1 situated $500 \mathrm{~m}$ south of Double Island Point-suggests-similar:primary stone artefact production activities (eg. core preparation). The existence of whelk shell at this site may reflect andesite quarrying by peoples residing at Tin Can Bay. If it is accepted that all stone artefact raw materials on Moreton Island are "available and readily accessible at Cape Moreton" (Richardson 1979:27), it seems incongruous that andesite should dominate "stone procurement and artefact manufacture" sites when andesite on1y accounts for $10.1 \%$ of stone artefacts.

\section{CONCLUSION AND FUTURE CONSIDERATIONS}

This initial archaeological investigation into the Cooloola Region resulted in the disclosure of a number of interesting patterns and problems. The survey strategy was directed towards efficiency and representativeness, using both probability and judgemental sampling designs.: Most of the research was directed towards the discerning of settlement-subsistence patterns, the results of which can direct future research in the area.

The next stage of the Cooloola Region Archaeological Research Project will have three primary objectives. First, it will seek to explain major patterns in the archaeological record discovered during stage 1, and to test associated explanatory hypotheses (eg. vineforest exploitation) Second, a number of areas considered representative of archaeological deposits will be excavated in order to better characterize the content of 'sites' as well as to add a chronological perspective to the project. Third, the survey will be extended to the remainder of the region, especially the western catchment and the lakes area to the south. Conclusive statements concerning the overall settlement-subsistence systems(s) operating in the Cooloola Region cannot be made until the archaeological record for the entire region has been characterized, and its full range of variability accounted for (see Ammerman 1981:66-67). At present I propose this as the most efficient procedure for achieving the aims of C.R.A.P.

\section{ACKNOWLEDGMENTS}

I wish to thank all those people who willingly gave assistance during this project. In particular, gratitude is expressed to Jay Hall, Cliff Thompson and Peter Dwyer. Jay Hall, Robert Neal and Ian Walters kindly commented on earlier drafts of this paper. 
REFERENCES CITED

Alfredson, G. 1983 St. Helena Island: A Changing Pattern of Exploitation? Australian Archaeology 17:79-86.

Alfredson, G. 1984 The Aboriginal use of St. Helena Island, Moreton Bay - The archaeological evidence. In R. J. Coleman, J. Covacevich and P. Davie (eds), Focus on Stradbroke: Nev information on North Stradbroke Island and Surrounding areas, 19741984, pp.1-8.. Brisbane: Boolarong Publications.

Ammerman, A. J. 1981 Surveys and archaeological research. Annual Reviev of Anthropology 10:63-88.

Beaton, J. M. 1977 Dangerous Harvest: Investigations in the 1ate prehistoric occupation of upland south-east central Queens 1 and. Unpublished PhD thesis, Australian National University, Canberra.

Bettinger, R. L. 1980 Explanatory/predictive models of hunter gatherers adaptation. Advances in Archaeological Hethod and Theory $3: 189-255$.

Binford, L. R. 1964 A consideration of archaeological research design. American Antiquity 29:425-441.

Bowdler, S. 1983 Rainforests: colonized or colonizer? Australian Archaeology $17: 59-66$.

Byrne, D. 1980 Dynamics of Dispersal: The place of silcrete in archaeological as semblages from the Lower Murchison, Western Australia. Archaeology and Physical Anthropology in Oceania 15:110-119.

Campbe11, J. B. 1982 New Radiocarbon results for north Queens 1 and prehistory. Australian Archaeology 14:62-66.

Canouts, V. 1977 Problem domains in the Santa Rosa Wash Project, Arizona. In M. B. Schiffer and G.J. Gumerman (Eds) Conservation Archaeology: A Guide for Cultural Resource Hanagement Studies, pp.135-143. New York: Academic Press.

Coaldrake, J. E. 1961 The ecosystems of the coastal lowlands ("wallum") of southern Queensland. CSIRO Australian Bulletin $238: 1-138$.

Coaldrake, J. E. 1962 The coastal sand dunes of southern Queens 1 and. Proceedings of the Royal Society of Queensland 62:101-116.

Crooks, J. 1982 Report on three excavations at Pumicestone Passage, Moreton Bay, southeast Queensland. Unpublished B.A.(Hons) thesis, University of Queensland, Brisbane.

Devitt, J. 1979 Fraser Island: Aboriginal resources and settlement patterns. Unpublished B.A.(Hons) thesis, University of Queensland, Brisbane. 
Dowling, R. M. and W. J. F. McDonald 1976 Moreton Region Vegetation Map Series. Explanatory notes for the Brisbane sheet scale 1:100,000. Botany Branch, Queensland Dept. of Primary Industries, Brisbane.

Draper, N. 1978 A model of Aboriginal subsistence and settlement in the Moreton Bay region of southeast Queensland. Unpublished B.A.(Hons) thesis, University of Queensland, Brisbane.

Dwyer, P. D., M. Hockings and J. 1979 Mammals of Cooloola and Beerwah. Proceedings of the Royal Society of Queens1and 90:65-84.

Dwyer, P. D., J. Kikkawa and G. J. Ingram 1979 Habitat relations of vertebrates in subtropical heathlands of coastal southeastern Queensland. In R.L. Specht (ed.), Ecosystems of the World. 9A. Heathlands and related Shrublands. Descriptive Studies, pp. 281-299. Amsterdam: Scientific Publishing Co.

Gillieson, D. S. and J. Hall 1982 Bevelling bungwall bashers: a usewear study from southeast Queensland. Australian Archaeology $14: 43-61$.

Godwin, L. 1982 Preliminary Archaeological Study of the Northeastern Coastal Zone Moreton Island. Report on file, Archaeology Branch, Department of Community Services, Brisbane.

Golson, J. 1971 Australian aboriginal plant foods: some ecological and culture-historical implications. In D. J. Mulvaney and J. Golson (eds.), Aboriginal Man and Environment in Australia, pp. 196-238. Canberra: Australian National University Press.

Gravatt, D. J. and G. J. Ingram 1975 Comments on the land vertebrates of Cooloola. Proceedings of the Ecological Society of Austra1 ia $9: 321-325$.

Greenslade, P. and C. H. Thompson 1981 Ant distribution, vegetation and soil relationship in the Cooloola-Noosa River area, Queensland. In A. N. Gillieson and D. J. Anderson (eds) Vegetation C1assification in Australia, pp. 192-207.cSIRo Canberra: Australian National University Press.

Ha11, J. 1980 Minner Dint: a recent Aboriginal midden on Moreton Is land, southeastern Queensland. University of Queensland Anthropology Museum Occasional Papers in Anthropology 10:94112 .

Hall, J. 1982a Sitting on the crop of the bay: an historical and archaeological sketch of Aboriginal settlement and subsistence in Moreton Bay, southeast Queensland. In S. Bowdler (ed.), Coastal archaeology in eastern Australia: proceedings of the 1980 Valla conference on Australian prehistory, pp. 79-95. Canberra: Department of Prehistory, RSPacs, Australian National University.

Ha11, J. 1982b The archaeological record of Moreton Island: a review and pre-mining salvage strategy proposal. Unpublished ms, Department of Community Services, Brisbane. 
Hal1, J. 1984 Exploratory excavation at Toulkerrie midden (LB:B175), Moreton Is land, S.E. Queensland. Queensland Archaeological Research 1:61-84.

Hall, J. and R. Robins 1984 A working model of Moreton Is 1 and prehistory: MRAP stage 1 . Queens 1and Archaeological Research $1: 85-94$.

Hiscock, P. 1984 A preliminary report on the stone artefacts from Colless Creek Cave, northwest Queensland. Queensiand Archaeological Research 1:120-151.

Horsfall, N. 1984 Theorizing about northeast Queensland prehistory. Queensland Archaeological Research 1:164-172.

Kamminga. J. 1981 The bevelled pounder: an Aboriginal stone artefact tool type from southeast Queensland. Proceedings of the Royal Society of Queens1and 92:31- 35.

Rerr, J. 1970 The Calooli Creek and Thannae railway, Tin Can Bay; Queensland's first private railway and first built locomotive. Queensland Heritage 2(3):14-20.

Lauer, P. K. 1977 Report on a preliminary ethnohistorical and archaeological survey of Fraser Island. University of Queensland Anthropology Museum Occasional Papers in Anthropology $8: 1-38$.

Laver, P. K. 1979 The museum's role in fieldwork: the Fraser Is land study. University of Queensland Anthropology Museum Occasional Papers in Anthropology 9:31-72.

Lee, R. B. 1969 !Kung Bushmen subsistence: a input-output analysis. In A. P. Vayda (ed.), Bnvironment and Culture Behaviour, pp. 4779. New York: Natural History Press.

Lourandos, H. 1983 10,000 years in the Tasmanian Highlands. Australian Archaeology 16:39-47.

Matson, R. G. and W. D. Lipe 1975 Regional sampling: a case study of Cedar Mesa, Utah. In J. W. Mueller (ed.), Sampling in Archaeology, pp. 124-143. Tucson: University of Arizona Press.

McDonald, W. J. F. and C. H. Thompson 1981 Camp Milo-King's Bore Tour. Rational Parks of soutb-eastern Queensland. Fieldtrip 6:6-15th August 1981. X111 International Botanical Congress, Sydney 1981 .

McKenzie, J. 1980 Capricorn coast beaches: coastal dune vegetation. Beach Conservation 40:2-6.

McKenzie, J. 1985 Mulgrave Shire northern beaches coastal vegetation. Beach Conservation 59:1-4. 
McNiven, I. J. 1984 Initiating archaeological research in the Cooloola Region, southeast Queensland. Unpublished B.A.(Hons) thesis, University of Queensland, Brisbane.

Meehan, B., P. Gaffey and R. Jones 1979 Fire to steel: Aboriginal exploitation of pandanus and some wider implications. University of Queensland Anthropology Museum Occasional Papers in Anthropology 9:73-96.

Meehan, B. 1980 Nutrition and storage: some further notes on Aboriginal use of pandanus in northern Australia. University of Queensland Anthropology Museum Occasional Papers in Anthropology $10: 23-24$.

Mueller, J. W. (ed.) 1975 Sampling in Archaeology. Tucson: University of Arizona Press.

Petrie, C. C. 1980 Tom Petrie's Reminiscences of Barly Queensland. Windsor, Victoria: Curry O'Neal.

Plog, S. 1976 Relative efficiencies of sampling techniques for archaeological surveys. In K. V. Flannery (ed) The Barly Mesoamerican Village,pp.136-158. New York: Academic Press.

Plog, S., F. P $10 g$ and W. Wait 1978 Decision making in modern surveys. Advances in Archaeological Method and Theory 1:383-421.

Redman, C. L. 1973 Multistage fieldwork and analytical techniques. American Antiquity 38:61-79.

Redman, C. L. 1974 Archaeological Sampling Strategies. Addison Hesley Module in Anthropology 55:1-34. Reading: AddisonWesley.

Reher, C. A. 1977 Subsistence and settlement along the Lower Chaco River. In C. A. Reher (ed) Settlement and Subsistence along the Lower Chaco River: The CGP Survey, pp.7-111. Albuquerque: University of New Mexico Press.

Richardson, N. 1979 The sources of raw material and their use in the manufacture of prehistoric stone artefacts on Moreton Island. Unpublished B.A.(Hons) thesis, University of Queensland, Brisbane.

Richardson, N. 1984 An archaeological investigation of sandmining lease SML 931 on North Stradbroke Island. In R. J. Coleman, J. Covacevich and P. Davie (eds), Focus on Stradbroke: Hev information on North Stradbroke Island and Surrounding areas, 1974-1984, pp.23-32. Brisbane: Boolarong Publications.

Roberts, R. P. and G. J. Ingram 1976 An annotated 1 ist of 1 and birds of Cooloola. The Sunbird $7(1): 1-20$.

Robins, R. P. 1983 This Widow Land: An Evaluation of Public Archaeology in Queensland Using Moreton Island as a Case Study. Unpublished M.A. thesis, University of Queensland, Brisbane. 
Robins, R. P. and J. Hall 1981 The Archaeology of Moreton Is land: A Preliminary Appraisal. Paper presented to 52nd ANZAAS Congress, Brisbane 12th May.

Roper, D. C. 1979 The method and theory of site catchment analysis: a review. Advances in Archaeological Method andrheory 2:119140 .

Sanders, W. T., J. R. Parsons and R. S. Santley 1979 Sampling strategies and surface survey in the Basin of Mexico. Appendix $E$ in The Basin of Mexico: Ecological Processes in the Evolution of a Civilization. New York: Academic Press.

Schiffer, M. B., A. P. Sullivan and T. C. K1inger 1978 The design of archaeological surveys. Wor1d Archaeology 10:1-28.

Seymour, J. 1981 The dunes of Cooloola. Ecos 30:3-11.

Stanton, J. P. n.d. The conservation of Cooloola. Queensland Conservation Council.

Stockton, J. 1974 Report on an Archaeological Survey in the Vicinity of Bribie Island, south-east Queensland. Unpublished B.A. (Hons) thesis, University of Queensland, Brisbane.

Stopher, P. R. and A. H. Meyburg 1979 Survey Sampling and Multivariate Analysis for Social Scientists and Engineers. London: Lexington Books.

Straker, D. 1968 Wide Bay, Cooloola and Laguna. Heybob 10:4-8.

Thompson, C. H. 1975 Coastal areas of southern Queensland: some land-use conflicts. Proceedings of the Royal Society of Queens 1and 86(18): 109-120.

Thompson, C. H. 1981 Podzol chronosequences on coastal dunes of eastern Austra1ia. Nature 291:59-61.

Thompson, C. H. 1983 Development and weathering of large parabolic dune systems along the subtropical coast of eastern Australia. Geomorphologie Supplementary Bulletin 45:205-225.

Thompson, C. H. and A. W. Moore 1984 Studies in Landscape Dynamics in the Cooloola-Noosa River Area, Queensland. 1. Introduction, General description and Research Approach. CSIRO Division of Soils Divisional Report No., 73.

Walker, J., C. H. Thompson, I. F. Fergus and B. R. Tunstall 1981 P1ant succession and soil development in coastal sand dunes of subtropical eastern Australia. In H. Shugart, D. Botkin and D. West (eds.), Forest Succession: Concepts and Application, pp. 107-131. New York: Springer-Verlag.

Walters, I. N. 1980 Vertebrate remains from two sites on Moreton Island, Queensland. Australian Archaeology 11:28-36. 
Ward, W. T., I. P. Little and C. H. Thompson 1979 Stratigraphy of two sandrocks at Rainbow Beach, Queensland, Australia, and a note on humate composition. Palaeogeography, Palaeoclimatology, Palaeoecology 26:305-316.

Webb, L. J. and J. G. Tracey 1975 The Cooloola Rainforests. Proceedings of the Ecological Society of Australia. 9:317-320.

Worseley, P. M. 1961 The utilization of natural food resources by an Australian Aboriginal tribe. Acta Bthnographica 10(1-2):153190. 